No. 20-6

\title{
Estimating the Cost Function of Connecticut Public K-12 Education: Implications for Inequity and Inadequacy in School Spending
}

\author{
Bo Zhao
}

\begin{abstract}
:
Facing legal challenges and public pressures, Connecticut needs an objective and rigorous study of its public education costs. This study is the first to estimate the cost function of Connecticut public K-12 education and to evaluate the equity and the adequacy in the state's school spending based on regression-estimated education costs. It finds large disparities across districts in education costs and cost-adjusted spending. Districts with the largest enrollments, the highest school-age-child-poverty rates, or the least amount of property wealth, on average, have the highest costs and the lowest cost-adjusted spending. A large percentage of the state's public school students are enrolled in districts where spending is inadequate relative to the predicted cost of achieving a common student performance target, which contributes to student underperformance. Thus, school districts, especially the high-cost ones, need a large amount of additional spending to improve student performance. The research approach used in this paper can be generalized and applied to other states.
\end{abstract}

JEL Classifications: H75, I21, I22, I28

Keywords: cost function, education costs, school spending, equity in education finance, adequacy in education finance

Bo Zhao is a senior economist for the New England Public Policy Center in the research department of the Federal Reserve Bank of Boston; his email is Bo.Zhao@bos.frb.org.

The author thanks Jeff Thompson, Rubén Hernández-Murillo, Andrew Reschovsky, the School and State Finance Project, and participants at the Federal Reserve Bank of Boston Research Department's Brown Bag Seminar, the annual meeting of the Federal Reserve System Committee on Regional Analysis, and the annual conference of the Association for Budgeting and Financial Management for helpful comments. Lan Ha provided excellent research assistance.

This paper presents preliminary analysis and results intended to stimulate discussion and critical comment. The views expressed herein are those of the author and do not indicate concurrence by the Federal Reserve Bank of Boston, the principals of the Board of Governors, or the Federal Reserve System.

This paper, which may be revised, is available on the website of the Federal Reserve Bank of Boston at https://www.bostonfed.org/publications/research-department-working-paper.aspx. 


\section{Introduction}

A series of high-profile court rulings in recent years has put Connecticut's education finance under the national spotlight. The Connecticut Coalition for Justice in Education Funding (CCJEF)—an umbrella nonprofit organization consisting of municipalities, local boards of education, teachers unions, advocacy groups, parents and grandparents, and public school students - filed a lawsuit in 2005, arguing that the state has failed to provide public school students with the adequate and equitable educational opportunity guaranteed by the state's constitution. In September 2016, a Connecticut Superior Court judge issued a landmark ruling on the case (CCJEF v. Rell), finding that the distribution of state education aid is irrational and unconstitutional, and requiring the state to make system-wide changes in its education policies. In particular, the judge "told the General Assembly it first had to determine how much money schools actually need to educate children and then must allocate the funds in a way that met that goal." ${ }^{1}$ However, in January 2018, the Connecticut Supreme Court reversed the lower court ruling with a 4-3 decision and deferred resolution of the issue to the state legislature.

Many people argue that the state legislature and administration still have not fully addressed the concerns about equity and adequacy in education funding. In 2017, the state adopted a new formula to distribute the Education Cost Sharing (ECS) grants, which are the largest source of Connecticut's K-12 education aid. In this formula, the state uses the foundation amount and the "need-student" weights to determine the education costs for each school district. The foundation is the amount of money that the state deems is needed to educate a typical public school student who does not have any additional learning needs. However, each year's foundation amount is

\footnotetext{
${ }^{1}$ Elizabeth A. Harris and Kristin Hussey, "In Connecticut, A Wealth Gap Divides Neighboring Schools," New York Times, September 11, 2016.
} 
"based on past foundation amounts and not derived using verifiable education spending data" (Connecticut School Finance Project 2019, p. 60). Also, it is not based directly on any student performance target (Connecticut School Finance Project 2019). While the current formula contains three "need-student" weights (low-income student, concentrated poverty, and English-learner) to account for higher costs for districts with greater student need, these weights are arbitrary and not derived from data analysis. ${ }^{2}$ In addition, there are concerns about the state's long-term commitment to this formula, given that Connecticut has rarely fully funded the ECS grants in the past 30 years (Moran et al. 2016; Sullivan 2018). ${ }^{3}$ In early 2019, the negotiations of the state budget for fiscal years 2020 and 2021 initially included discussions among state legislators and the state's new governor about changing the education aid formula and creating a task force that would conduct an education cost study. ${ }^{4}$ However, the final approved state budget for the two years preserves the current aid formula and does not include an education finance task force. ${ }^{5}$

There remains a need for an objective and rigorous study of Connecticut's education costs that would be the foundation of an equitable and adequate state education aid formula. To fill this knowledge gap, this paper first estimates the cost function of Connecticut public $\mathrm{K}-12$ education. Then, I use the cost function to estimate how much it costs each district to achieve a common student performance target level, as measured by statewide standardized testing, given student

\footnotetext{
${ }^{2}$ Whereas a typical student without additional learning needs receives a weight of 1.0 in the current formula, a lowincome student receives a weight of 1.3, and an English-learner student receives a weight of 1.15 (Connecticut School Finance Project 2019). Furthermore, the state gives an additional weight of 0.05 to each low-income student attending a district in which more than 75 percent of the students are from low-income households.

${ }^{3}$ In recent years, Connecticut stopped running the ECS formula and instead distributed ECS grants via block grants. In October 2017, the state legislature passed a law that calls for the phasing in of full funding of the ECS grants over a 10-year period that began with fiscal year 2019 .

${ }^{4}$ A state law passed in October 2017 created the Connecticut Achievement and Resource Equity in Schools Commission, which was to make recommendations by April 1, 2018, for reforming the state education aid formula. However, as of September 2019, the commission had not produced the required report.

${ }^{5}$ Meanwhile, a separate bill calling for a task force to study the education aid formula, H.B. 7355 , failed to advance in the state legislature.
} 
characteristics and other cost factors that are outside the direct control of local officials at any given point in time. The analysis shows the disparities in education costs across school districts and the equity and adequacy of each district's spending relative to its costs for achieving a common student performance target level. Finally, this paper makes recommendations on how much additional spending is needed for all districts to achieve some common student performance target levels.

To the best of my knowledge, this paper is the first cost function study of Connecticut public $\mathrm{K}-12$ education. It is the first paper to evaluate the equity and adequacy of school spending based on regression-estimated education costs for each district to achieve common target levels for student test performance. This research is timely and policy relevant, as there is still an ongoing debate among Connecticut policymakers, practitioners, and advocates on how to further reform the state education aid system and make it more equitable and adequate.

This paper also makes two improvements over previous cost studies in controlling for district efficiency. First, it adds fixed effects for labor market areas (LMAs) to control for timeinvariant differences across LMAs in the labor pool (teachers and school managers), available technologies in teaching and school management, and the competitiveness of the education market. Except for those by Downes and Pogue (1994) and Duncombe and Yinger (2007), previous studies do not include any geographic-level fixed effects. ${ }^{6}$ This paper's second, small improvement over previous studies is the addition of dummy variables for school districts bordering another state.

\footnotetext{
${ }^{6}$ See, for example, Duncombe, Ruggiero, and Yinger (1996), Duncombe and Yinger (1997, 1998, 1999, 2000, 2005a, 2005b, 2006, 2011a, and 2011b), Duncombe (2002, 2006, and 2007), Duncombe, Lukemeyer, and Yinger (2003), Imazeki and Reschovsky (2003, 2004, and 2006), Reschovsky and Imazeki (2003), Imazeki (2001 and 2008), Gronberg et al. (2004), and Gronberg, Jansen, and Taylor (2011). To the best of my knowledge, Downes and Pogue (1994) and Duncombe and Yinger (2007) are the only papers to include fixed effects for school districts. I tried using district fixed effects in this paper, but there is not enough variation within districts to identify the regression coefficients, since the cost factors do not change substantially or at all over time.
} 
Compared with interior districts, border districts may face different competition for students and be exposed to a different labor pool and different technologies used in teaching and school management.

While it is based on Connecticut data, this paper could be relevant and useful for other states, because it addresses issues that are not unique to Connecticut. Many other states face similar challenges in providing adequate and equitable education funding and could benefit from this research when crafting appropriate policy solutions. Furthermore, though there are differences among the states' public K-12 education systems, Connecticut's system is similar to those of other states in many aspects (Table 1). For example, the percentage of minority students (as a proxy for low-income students) in the Connecticut system is close to the national average. Like every other northeastern state, except Vermont, Connecticut relies heavily on local revenues to fund school districts, with more than half of the total district revenue coming from local sources. Similar to school districts in the other New England states, Connecticut's school districts do not have taxing authority and instead are fiscally dependent on cities and towns. Since there is no local income tax or general sales tax, property tax is virtually the only tax revenue source for local governments in the region. In addition, student performance in Connecticut is close to the levels in other northeastern states. Given these similarities, this paper's research approach and findings can, to some extent, be generalized and applied to other states.

\section{Conceptual Framework}

This paper follows a conceptual framework used in many previous studies, including those by Duncombe and Yinger (2007, 2011a, and 2011b) and Baker (2009). In this framework,

$$
E=\frac{C}{e}
$$


where $E$ is a school district's spending, $C$ is education costs, and $e$ is a school district's efficiency in delivering education outcomes.

Duncombe and Yinger (2007, 2011a, and 2011b) define education costs $(C)$ as the amount a school district must spend to achieve a given student performance level while using the best available technology for teaching and school management. Unlike spending, education costs cannot be directly observed. In theory, education costs depend on the following measurable factors:

$$
C=f(S, W, P, N),
$$

where $S$ is education outcome, $W$ is labor input prices (for example, teacher salaries), $P$ is "student need" measures, and $N$ is student enrollment. In general, education costs are expected to increase with education outcome, teacher salaries, and student need. The relationship between education costs and student enrollment is likely to be nonlinear due to economies of scale.

Due to data constraints, education outcome $(S)$ is often empirically measured in terms of student performance in state-administered standardized test and/or high school graduation rates. States collect these student performance data in order to evaluate schools and enforce school accountability policies. However, other types of education outcome either are not measured (for example, foreign language skills) or cannot be measured (for example, artistic ability). As a result, education outcome used in this paper (as in previous papers) is narrowly defined and does not cover all school-provided education services.

Student-need measures are characteristics that are outside the direct control of local officials at any given point in time and make it harder and more expensive for a school district to achieve a given student performance level. For example, students from low-income families are 
likely to receive less time and/or resources from parents and to experience a less stable housing situation compared with students from high-income families. Therefore, a school district with a greater percentage of low-income students may have to spend more to achieve a given student performance level.

A school district's efficiency $(e)$ is standardized to range from 0 through 1 , with 1 being the highest level of efficiency. The lower a district's efficiency is, the higher its spending would have to be to achieve the same education outcome given the same education costs. Broadly speaking, there are at least two sources of inefficiency (Duncombe and Yinger 2011a): (1) not employing the most effective teachers and the best available (broadly defined) technology for teaching and school management or even spending wastefully by, for example, purchasing outdated lab equipment; and (2) spending on subjects — such as sports, music, art, and foreign languages - that are not covered by the state's standardized testing but are demanded by students' parents. Spending on such subjects may be considered inefficient because it does not directly increase students' standardized test performance. ${ }^{7}$

It is crucial to control for efficiency in the cost regressions. Otherwise, cost estimates could be biased if they are correlated with inefficiency. However, it is rather difficult to empirically account for efficiency because efficiency is not directly observed. Duncombe and Yinger (2011a) review the three empirical approaches that scholars have used to deal with efficiency: (1) including district fixed effects, (2) using data envelopment analysis (DEA), and (3) including observable factors that can be conceptually linked to efficiency and therefore act as proxies for efficiency. Each approach has its own pros and cons. (See Duncombe and Yinger [2011a] for a more detailed

\footnotetext{
${ }^{7}$ In this sense, the term "efficiency" is narrowly defined in this paper. It means test-performance efficiency if education outcome is measured in terms of test proficiency or test scores. Alternatively, it means high-school-graduation-rate efficiency if education outcome is measured in terms of high school graduation rates.
} 
discussions.) I use the third approach because it strikes a good balance between conceptual plausibility and empirical feasibility (including data requirements).

Therefore, I model efficiency as follows:

$$
e=f(M, H, D)
$$

where $M$ represents voters' incentive to monitor the school district's spending, $H$ measures the competitiveness of the education market, and $D$ is parents' demand for education on untested subjects. In theory, the stronger the voters' incentive to monitor a school district's activities, the less that school district will spend wastefully (Duncombe and Yinger 2011a and 2011b). Similarly, the more competition a school district faces in attracting students, the more likely it is to employ the most effective teachers and the best available technology for teaching and to run its schools efficiently (Hoxby 2000; Imazeki and Reschovsky 2004).

Next, I take a logarithmic transformation of equation (1), substitute $C$ and $e$ with equations (2) and (3), respectively, and obtain:

$$
\log E=\log f(S, W, P, N)-\log f(M, H, D)
$$

This equation provides guidance on the empirical specification.

\section{Empirical Methodology}

Following equation (4) and previous studies, this paper estimates this reduced-form equation:

$$
\log E_{i t}=\alpha_{0}+\alpha_{1} S_{i t}+\alpha_{2} P_{i t}+\alpha_{3} g\left(N_{i t}\right)+\alpha_{4} M_{i t}+\alpha_{5} D_{i t}+\alpha_{6} H_{i t}+L_{j}+T_{t} \text {, }
$$

where $g(N)$ is a nonlinear function of enrollment that represents economies of scale, $L$ is fixed effects for labor market areas (LMAs), $T$ is fixed effects for years, $i$ is an index for school districts, 
$j$ is an index for labor market areas, $t$ is an index for years, and the remaining symbols $-E, S, P$, $N, M, D$, and $H$-represent the same factors as those in equation (4). ${ }^{8}$ Broadly speaking, I categorize $P$ and $g(N)$ as cost factors and $M, D, H$, and $L$ as efficiency variables. By controlling for LMA fixed effects, this paper uses variation within LMAs and over time to identify the regression coefficients. Standard errors are clustered at the school-district level to allow for correlations within districts.

\section{Dependent Variable}

The dependent variable $(\log E)$ is the logarithm of current spending per pupil. Current spending excludes expenditures on capital outlays and debt services, which tend to be lumpy and are not directly linked to student performance. ${ }^{9}$ Following a standard practice in the literature, I remove payments to private schools and spending on transportation and food services from the current spending sum. A few districts in Connecticut send their high school students to private schools and pay these students' tuition. Expenditures on transportation and food services are excluded because they do not directly contribute to academic performance, and because transportation spending depends heavily on geographic factors. ${ }^{10}$

\section{Cost Factors}

\footnotetext{
${ }^{8}$ The U.S. Bureau of Labor Statistics defines a labor market area as "an economically integrated area within which individuals can reside and find employment within a reasonable distance or can readily change jobs without changing their place of residence." (See https://www.bls.gov/lau/laufaq.htm\#Q06.) By this definition, there are six federally designated labor market areas in Connecticut. I also tried using county fixed effects instead of LMA fixed effects. (There are eight counties in Connecticut, which mostly overlap with LMAs.) The regression results are similar to those using LMA fixed effects.

${ }^{9}$ For example, Martorell, Stange, and McFarlin (2016) find that school facility investments have no effect on student achievement.

${ }^{10}$ Transportation and food services expenditures are relatively small. For example, on average, they were less than 8 percent of total current spending in Connecticut in 2013 (the last year in this paper's sample period). I find that including spending on transportation and food services has virtually no impact on the cost factors, except to somewhat raise the coefficient on the dummy variable for regional school district. This likely reflects that regional districts tend to be rural and encompass a large area; therefore, it costs them more to provide school transportation on a per-pupil basis.
} 
I use two criteria to select cost factors $(P$ and $g(N))$. First, the reason these factors affect education costs should be economically intuitive and straightforward. Previous studies conducted for other states provide a list of potential cost factors to examine with the Connecticut data. Second, the cost factors should be statistically significant at the 10 percent level or lower, because one goal of this research is to recommend including the scientifically defensible cost factors in the state aid formula.

\section{Education Outcome}

The literature tends to use states' standardized test results to measure education outcome $(S)$. This is because often the data on test results are readily available, since states collect and publish them, and because standardized test results are arguably the most important metric in the school accountability system. Following the literature, this paper uses Connecticut's standardized test results as the preferred measure of education outcome. I also explore alternative measures, including high school graduation rates and the percentage of high school graduates pursuing higher education. Regardless of how it is measured, education outcome is likely to be endogenous. ${ }^{11}$ This paper employs an instrumental variables (IV) approach to correct for endogeneity bias. Duncombe (2007), Duncombe and Yinger (2011a and 2011b), and Baker et al. (2018) recommend using characteristics of school districts ("neighbor districts") that are in the same labor market area as the school district in question ("home district") as IVs. In theory, neighbor districts and the home district compete for students and state aid dollars that follow students, as families with school-age children choose where to live within a labor market area based partly on the school

\footnotetext{
${ }^{11}$ Numerous studies show that school expenditures have a positive effect on students' achievement. See, for example, Elliot (1998), Guryan (2001), Card and Payne (2002), Deke (2003), Kinnucan, Zheng, and Brehmer (2006), Chaudhary (2009), Roy (2011), Nguyen-Hoang and Yinger (2014), Jackson, Johnson, and Persico (2016), Lafortune, Rothstein, and Schanzenbach (2018), Hyman (2017), and Gigliotti and Sorensen (2018).
} 
districts. Therefore, neighbor districts' characteristics that affect their own student performance could influence the home district's student performance through competition between the districts or through copycat behaviors. In this way, neighbor districts' characteristics could be correlated with the home district's student performance. On the other hand, there is no obvious reason to believe that neighbor districts' characteristics directly affect the home district's spending, if not through influencing the home district's student performance.

However, the theory does not specify exactly which characteristics of neighbor districts are valid IVs. Duncombe (2007) and Duncombe and Yinger (2011a and 2011b) acknowledge that they rely on statistical tests to select IVs. Thus, it is not surprising to see that these authors use different neighbor-district characteristics as IVs in different papers based on different states' data.

I apply the following criteria for selecting IVs from neighbor districts' characteristics. First, the economic explanation for why the selected characteristics affect student performance should be simple and intuitive. Second, the selected characteristics can be plausibly assumed to be outside the direct control of local officials at any given point in time. Third, the selected characteristics of neighbor districts should pass the under-identification test with the p-value at or below 5 percent. Fourth, the selected characteristics of neighbor districts should pass the over-identification test (that is, the Hansen J Statistic test) with the p-value at or above 10 percent. Lastly, each IV should be significant at or below the 10 percent level in the first-stage regression. In this paper, two neighbor-district characteristics satisfy these IV selection criteria: the average percentage of the 
property tax base from businesses and the average percentage of adults without a high school degree, weighted by student enrollment of neighbor districts. ${ }^{12}$

The theory gives an ambiguous prediction on the sign of these IVs in the first-stage equation. This is because the two mechanisms through which neighbor districts affect the home district - competition and copycat behaviors — generate opposite predictions. Therefore, the sign on the IVs must be determined empirically.

\section{Efficiency Variables}

In theory, voters' incentive to monitor a school district's spending $(M)$ depends on local revenue capacity, tax price, and voter characteristics. Voters could have a lower incentive to monitor a school district if the local government has a greater revenue capacity to support school spending. Therefore, local revenue capacity, which is often based on the property tax base and/or income, is expected to be positively related to school spending. In Connecticut, the property tax base is measured by the Equalized Net Grand List (ENGL), which is the fair market value of properties subject to property taxes, adjusted by the state for differences across cities and towns in assessment practices.

Voters' incentive to monitor a school district increases with the tax price. Voters face a lower tax price if a larger share of a school district's total revenue is funded by non-local sources (that is, the federal and state governments), or if a higher share of local property taxes are paid by businesses and nonresidents. Therefore, the percentage of a school district's total revenue from

\footnotetext{
${ }^{12}$ The percentage of the property tax base from businesses is defined as the assessed value of commercial, industrial, public-utilities, and other properties as a percentage of total assessed property value. The Connecticut Office of Policy and Management counts apartments as part of commercial properties and categorizes vacant land, use assessment properties, and 10 Mill forest land as "other" properties.
} 
federal and state sources and the percentage of the property tax base that comes from businesses and nonresidents are expected to have a positive effect on school spending.

Fiscally conservative voters are more likely to engage in monitoring government activities. Therefore, school spending is expected to decrease with the percentage of registered Republican voters (a proxy for fiscally conservative voters).

The impact of the elderly on school spending is theoretically ambiguous. On the one hand, older voters, who presumably have more spare time and lower opportunity costs, may be more likely to engage in monitoring government activities to lower school spending. On the other hand, some previous studies find that the impact of the elderly on school spending can be positive if the elderly are long-term residents and loyal to their communities and schools (Fletcher 2006) or if the capitalization of school spending in house prices benefits the elderly homeowners (Hilber and Mayer 2009). Hence, I need to empirically test whether school spending decreases or increases with the percentage of the population that is aged 65 and older. ${ }^{13}$ In addition, Duncombe (2006) suggests that voters' incentive to monitor a school district's activities might vary with their education background and homeownership status.

Parents' demand for education on untested subjects $(D)$ could be correlated with their educational attainment level. Therefore, this paper includes the percentage of adults with a bachelor's degree or higher as a proxy variable for parents' preference.

Labor market area (LMA) fixed effects $(L)$ help control for a school district's efficiency in two ways. First, school districts in different LMAs face different pools of teachers and school

\footnotetext{
${ }^{13}$ One may also hypothesize that communities with more school-age children are likely to pay more attention to school spending, which could affect schools' efficiency incentive. When I include the percentage of population aged 5 through 17 in the regression, it is not statistically significant.
} 
managers, who may have different qualities and use different technologies for teaching and school management. Second, school districts in different LMAs face different competition in attracting students and therefore have different incentives to efficiently deliver student performance. ${ }^{14}$

It should be noted that LMA fixed effects also help control for differences in teacher salaries $(W)$ across LMAs. The literature presents two other approaches to accounting for teacher salaries. Duncombe (2002 and 2007), Duncombe, Lukemeyer, and Yinger (2003), and Duncombe and Yinger (1997, 2000, 2005a, 2007, 2011a, and 2011b) include actual teacher salaries in the estimation equation. Because teacher salaries are endogenous, they use IVs to correct for estimation bias. Imazeki and Reschovsky (2003, 2004, and 2005), Reschovsky and Imazeki (2003), and Baker et al. (2018) include the Education Comparable Wage Index (ECWI) as a proxy measure of teacher salaries. The National Center for Education Statistics (NCES) develops this index using the salaries of college graduates in the school district's LMA who are not teachers. By excluding teacher salaries, the ECWI is plausibly exogenous to school districts' spending. Because the ECWI is defined at the LMA level and does not change substantially in a short time (especially after being scaled by the state-level ECWI), I do not concurrently include the ECWI and LMA fixed effects in the equation. When I include the ECWI without LMA fixed effects, the ECWI is positive but not statistically significant.

In addition, this paper includes three dummy variables for school districts bordering Massachusetts, New York, and Rhode Island, respectively, to further control for district efficiency. A school district bordering another state competes not only with other Connecticut school districts

\footnotetext{
${ }^{14}$ To measure market competitiveness, Hoxby (2000) develops a Herfindahl index based on enrollment distribution across school districts within the education markets. Imazeki and Reschovsky (2004) and Baker (2018) include this Herfindahl index in their regressions. However, because this index is often defined at the LMA level and does not change substantially in a short time, I do not include it and LMA fixed effects in the same regression. When I include the Herfindahl index without LMA fixed effects, it is not statistically significant.
} 
for students, teachers, and school managers, but also with school districts in the adjacent state, which could therefore affect its efficiency incentive. A border district may also be exposed to different labor pools and different teaching and management technologies used in the neighboring state.

IV. Data

This paper conducts the analysis at the district level, not at the school level, for three reasons. First, Connecticut does not require financial information to be reported at the school level. The Census Bureau's Annual Survey of School System Finances (F-33), which provides school finance data to the NCES's Common Core of Data, also collects data at only the district level. Therefore, there are no available data for determining per-pupil spending at the school level. Second, almost all other variables used in the regressions are available at the district or city/town level, but not at the school level. ${ }^{15}$ Third, Connecticut determines and allocates state education aid to school districts, not directly to schools. Because one goal of this research is to help the state improve the education aid formula, it is appropriate to analyze district-level data.

Following a standard practice in the literature, I remove charter schools and other nonregular local education agencies from the data, since they are rather different from traditional school districts. ${ }^{16}$ I make two further adjustments to ensure that all districts in the final sample have complete $\mathrm{K}-12$ grades and are thus more comparable and more suitable for regression

\footnotetext{
${ }^{15}$ See Appendix Table 1 for data sources.

${ }^{16}$ During the 2009-2013 period, the number of charter schools did not change in five out of six Connecticut LMAs, ranging from zero to eight. The remaining LMA saw the number of charter schools drop from five in 2009-2011 to four in 2012. Furthermore, the enrollment in charter schools was small and equivalent to between 0.3 and 1.8 percent of the total enrollment in traditional public schools in the same LMA. Given that charter schools play a relatively stable and small role in Connecticut public K-12 education, the LMA fixed effects should help to control for the competition pressure from charter schools (if any) on traditional school districts in each LMA, which could potentially affect the efficiency incentive of traditional school districts. Estimating the education costs for charter schools and other non-regular local education agencies is beyond the scope of this paper and deserves a separate study.
} 
analysis. First, I remove 19 districts that do not operate their own high school and do not belong to a regional school district with a high school. These districts instead send their high school students to designated high schools in neighbor districts or to private high schools. They pay these students' tuition based on agreements with the recipient districts or private schools. Second, I identify districts that do not operate their own high school but do belong to a regional high school district, aggregate them to the regional district level, and create eight pseudo regional $\mathrm{K}-12$ districts. However, three of these pseudo districts have to be dropped from the regression sample, because two of them are missing data on student performance and the other is missing data on both student performance and a cost factor. As a result, this paper has 117 districts in the regression sample, including 103 local unified $\mathrm{K}-12$ districts, nine regional unified $\mathrm{K}-12$ districts that operate all grades for their member towns, and five pseudo regional $\mathrm{K}-12$ districts. This sample covers about 94 percent of the state's total enrollment in public schools during the 2009-2013 period.

The sample period of 2009 through 2013 was determined by data availability, especially data on student test results. ${ }^{17}$ Connecticut has changed standardized tests several times since the mid-1980s. Public elementary and middle school students took different generations of the Connecticut Mastery Test (CMT) from 1985 through 2014, and public high school students took different generations of the Connecticut Academic Performance Test (CAPT) from 1995 through $2015 .{ }^{18}$ Since 2015, public school students have been required to take the Smarter Balanced Test. The Connecticut Department of Education emphasizes that different generations of these tests are

\footnotetext{
${ }^{17}$ I use the Consumer Price Index for the Northeast Region to inflate spending and other financial variables to 2013 dollars.

${ }^{18}$ Public elementary and middle school students were required to take the CMT 1st Generation from 1985 through 1992, the CMT 2nd Generation from 1993 through 1999, the CMT 3rd Generation from 2000 through 2004, and the CMT 4th Generation from 2006 through 2013. Public high school students were required to take the CAPT 1st Generation from 1995 through 2000, the CAPT 2nd Generation from 2001 through 2006, and the CAPT 3rd Generation from 2007 through 2015. In 2015, public high school students took both the CAPT test and the Smarter Balance Test.
} 
not comparable and advises against combining data from different test periods. Therefore, I have to use data from only one test period. If I were to use results from the current test, it would result in a sample period of only two years, 2015 and 2016. This is because at the time of this analysis, the Common Core of Data included finance data only through 2016. (The ACS five-year estimates included explanatory variables only through 2017.) Using such a small data set will yield limited test power to detect cost factors. As the best alternative, I use data from 2009 through 2013, a period when Connecticut students took the CMT $4{ }^{\text {th }}$ Generation (elementary and middle school) and CAPT $3^{\text {rd }}$ Generation (high school) tests, and a period for which the ACS five-year estimates are available. ${ }^{19}$

While this paper does not use the most recent test results, its findings are still informative and relevant to the current policy debate. The cost function of public education is believed to be relatively stable, regardless of the time periods and the test vehicles that the state utilizes. Using data from Kansas and Missouri, Duncombe (2006) and Duncombe and Yinger (2011a), respectively, show that the cost function estimates are not sensitive to the time periods of data that are used and are reliable for forecasting purposes. As the next section of this paper shows, the cost coefficients in my regressions remain fairly robust no matter what test and non-test measures of education outcome are used in the regression. Furthermore, the same research method can be easily applied to data from the Smarter Balanced Test when more information becomes available.

\footnotetext{
${ }^{19}$ The earliest ACS 5-year estimates were collected over the 2005-2009 period. This paper treats the 2005-2009 ACS data as the 2009 data. Doing so makes the endogeneity of the ACS variables less likely, since the 2009 current spending per pupil is unlikely to affect the ACS data collected in the 2005-2008 period. I also tried treating the 2005-2009 ACS data as the 2007 data (that is, the middle year). This change has little impact on the regression results. However, this treatment of the ACS data has a drawback in that the 2007 current spending could potentially affect the ACS variables collected in 2008 and 2009 if families moved across school districts in response to changes in school spending.
} 
For simplicity, I aggregate test results from the CMT $4^{\text {th }}$ Generation and the CAPT $3^{\text {rd }}$ Generation into a single variable as the preferred measure of student performance in each district. Each year of the sample period, public school students in grades 3 through 8 were required to take the CMT $4^{\text {th }}$ Generation in math, reading, and writing, while grade-10 students were required to take the CAPT $3{ }^{\text {rd }}$ Generation in math, reading, and writing. ${ }^{20}$ For each test subject, I calculate a weighted average of the percentage of students who are at or above the proficiency level across grades in each district, using the number of tested students in each grade as a weight. Then, I take the simple mean of the three weighted average percentages of students who are at or above the proficiency level in math, reading, and writing as the aggregate measure of student performance in each district. I also try various alternative measures of student performance as part of the robustness checks, including test scores, high school graduation rates, the percentage of high school graduates pursuing higher education, and a value-added measure of student test performance based on the matched student cohorts.

V. Results

Regression Results

Table 2 shows regression results from the preferred specification. First, student performance is confirmed to be endogenous and needs to be instrumented. The endogeneity test's p-value is close to 0.05 . Second, the two selected IVs - neighbor districts' percentage of the property tax base from businesses and neighbor districts' percentage of adults without a high school degree—are shown to pass the Kleibergen-Paap under-identification test (with a p-value of 0.017) and the Hansen J

\footnotetext{
${ }^{20}$ The state also tested public school students in science, but only those in grades 5, 8, and 10 .
} 
over-identification test (with a p-value of 0.218 ). In addition, the IVs are significant at the 1 percent and 10 percent levels, respectively, in the first-stage regression.

In the second-stage regression, the student test performance measure is positive and significant at the conventional level. ${ }^{21} \mathrm{~A} 1$ percentage point increase in the percentage of students who are at or above the proficiency level results in, on average, a 1 percent increase in current spending per pupil. This result is consistent with the theory's prediction and the previous empirical finding that higher student achievement requires more school spending. In addition, most of the efficiency variables are significant and have the expected sign. ${ }^{22}$

The four cost factors are positive and significant in the second-stage regression when student test performance is held constant. ${ }^{23}$ First, a district with a higher percentage of school-age children from families living in poverty has to spend more to achieve a given student performance level. A 1 percentage point increase in the percentage of school-age children from families living in poverty results in, on average, a 1.2 percent increase in current spending per pupil. ${ }^{24}$ This is because, to achieve the same academic proficiency, students from low-income families face more challenges than students from high-income families do. For example, their parents may be less able to dedicate time and/or financial resources to helping with their education. They are more

\footnotetext{
${ }^{21}$ If I do not treat student test performance as endogenous and simply run a regression without IVs, the coefficient on student test performance will become negative and not significant. This is likely because large poor cities have relatively high spending per pupil and the lowest student test performance in the state.

${ }^{22}$ When I use the percentage of total revenue from federal sources and the percentage of total revenue from state sources separately in a regression, instead of grouping them together, this change has virtually no impact on the cost coefficients.

${ }^{23}$ When I include the percentage of students in grades 9 through 12 to test a hypothesis that it is more costly to educate high school students than to educate elementary and middle school students, this new variable is positive, but highly insignificant.

${ }^{24}$ To explore a potential nonlinear relationship between log of current spending per pupil and the measure of lowincome students, I include the square of the percentage of school-age children from families living in poverty. The square term is not statistically significant. I also test the interactions of the school-age-child-poverty rate with population density, log of population density, the percentage of students who are black, and the percentage of students who are Hispanic. None of these interaction terms are statistically significant.
} 
likely to be English learners ${ }^{25}$ and to have disabilities. ${ }^{26}$ They are also more likely to experience an unstable and even unsafe living situation and to relocate frequently. ${ }^{27}$

Second, a district with a higher percentage of students living in single-parent or non-family

households has to spend more to achieve a given student performance level. If students live in single-parent or non-family households, they are likely to receive less support outside of school. The estimate implies that a 1 percentage point increase in the percentage of students living in

\footnotetext{
${ }^{25}$ I tried including individually the percentage of English-learner students and the percentage of students enrolled in public schools who are foreign-born. These variables are not statistically significant, likely because they are highly correlated with the percentage of school-age children from families living in poverty and with the percentage of public school students living in single-parent or non-family households. Part of the effect of English-learner students, if not all, is likely captured by the percentage of school-age children from families living in poverty and the percentage of students living in single-parent or non-family households.

${ }^{26}$ I do not include the percentage of special-education students for two reasons. First, the percentage is likely to be endogenous. Districts have a financial motive and discretion in determining students' special-education status, given that special education is expensive and the state does not consider the number of special-education students in distributing education aid to school districts. Local news publications (Jacqueline Rabe Thomas, "State Intervenes in Hartford's Treatment of Students with Disabilities," CT Mirror, August 26, 2011; Jacqueline Rabe Thomas, "State: Bridgeport 'Systematically Violated' Special Education Laws," CT Mirror, January 24, 2014; Brian McCready, "Oxford Parents Question Special Education Services," Oxford Patch, October 11, 2018) report that some Connecticut districts have been accused of intentionally and systematically denying special education to students with disabilities. Second, the percentage of special-education students is highly correlated with the percentage of school-age children from families living in poverty and with the percentage of public school students living in single-parent or non-family households. Including these variables concurrently would create a multi-collinearity problem. Even though this paper does not include a direct measure of special-education students, some of their effects, if not all, are likely captured by the percentage of school-age children from families living in poverty and the percentage of public school students living in single-parent or non-family households, due to the high correlations among these variables. In addition, I explored using disability data that were collected from the ACS. However, the ACS changed the disability questions in 2008, resulting in new questions that are incomparable to the previous years' questions or the Census 2000 disability data. In fact, the ACS website no longer shows disability data from 2005 through 2007. Since I use the 2008-2012 ACS 5-year estimates (the first ACS 5-year data with the new disability questions) as the 2012 data, it means that I have only two years of ACS disability data (2012 and 2013) within this paper's sample period, which is insufficient for regression analysis.

${ }^{27}$ I tried including the percentage of students who are homeless as a potential cost factor. The variable is positive, but highly insignificant, likely due to the poor quality of the homeless data. Federal and state laws require schools to provide transportation and other costly services to homeless students; therefore, districts may have a financial incentive to under-identify homeless students (Jessica Glenza, "Connecticut Struggles to Identify Homeless Students: New Haven Tally Doubled since '08," New Haven Register, August 24, 2013). Many districts simply rely on selfidentifying by homeless families and students, who may be reluctant to do so for fear of stigma. In my data, nearly 56 percent of district-year observations reported zero homeless students. During the 2009-2013 period, the highest percentage of students who were identified as homeless among Connecticut school districts was 3.9 percent for New Britain in 2010. Housing advocates believe that student homelessness is more widespread and severe than the official data suggest.
} 
single-parent or non-family household leads to, on average, a 0.3 percent increase in current spending per pupil. ${ }^{28}$

Third, a district with fewer than 2,000 enrolled students has to spend more to achieve a given student performance level. Such small districts are not able to enjoy the economies of scale that benefit larger districts. ${ }^{29}$ I choose an enrollment of 2,000 as the size cutoff, following previous studies. Based on a comprehensive review of the cost function studies since 1980, Andrews, Duncombe, and Yinger (2002) conclude that a district with about 2,000 to 4,000 students may experience sizable cost savings, compared with a district with 500 or fewer students. Baker et al. (2018) show that districts with fewer than 2,000 students spend more per pupil, when everything else is held constant.

Finally, the cost of achieving a given student performance level is higher for regional school districts than for local school districts, perhaps due to costs associated with coordination among the member towns. These regional school districts were established before the late 1970s and therefore can be plausibly taken as a given during the sample period.

Table 3 shows that the cost factors are fairly robust. First, I replace the percentage of school-age children from families living in poverty with the percentage of students eligible for free or reduced-price lunch (commonly abbreviated as FRPL). The latter has been used extensively in

\footnotetext{
${ }^{28}$ If the percentage of students who are black and the percentage of students who are Hispanic are added as independent variables to the equation, the percentage of students living in single-parent or non-family households will become insignificant. This is because the percentage of students living in single-parent or non-family households is highly correlated with the two race and ethnicity variables.

${ }^{29}$ In theory, the state could mandate small districts to consolidate. However, until such state-level policy occurs, the size of district enrollment remains outside the direct control of local officials at any given point in time. It is also worth noting that the estimated coefficients on the dummy variable for an enrollment of fewer than 2,000 students and the dummy variable for a district being a regional school district are similar in the cost regression (Table 1). This suggests that on average, school district consolidation may not produce net cost savings.
} 
previous studies and states' education aid formulas, including Connecticut's current formula, to account for low-income students. ${ }^{30}$ However, concerns have increasingly been raised about the validity of FRPL, especially since the Community Eligibility Provision (CEP) in the federal Healthy, Hunger-Free Kids Act of 2010 took effect. ${ }^{31}$ Therefore, many states have been seeking alternative, more reliable measures of low-income students to replace FRPL in the education aid formulas.

Column 2 shows that the coefficient on the percentage of students eligible for FRPL is positive and significant. The coefficient is smaller than the coefficient on the percentage of school-

\footnotetext{
${ }^{30}$ I also tried replacing the percentage of school-age children from families living in poverty with the percentage of the population receiving Temporary Assistance for Needy Families (TANF). In that regression, the TANF variable is positive and significant. However, the TANF variable significantly underestimates the number of low-income students, since only about 1 percent of Connecticut's population received TANF in the 2009-2013 period. In addition, I tried using the number of children under age 19 and enrolled in Husky A (Connecticut's Medicaid for children) per pupil as an alternative measure of low-income students. This variable is positive but not significant, likely because it reflects not only poverty, but also policy changes. The state significantly expanded the Medicaid program during this period, which resulted in a continuous increase in the Husky A enrollment, despite economic fluctuations.

${ }^{31}$ The CEP allows all students, not just low-income students, to receive free meals if their districts or schools qualify and participate. To qualify for the CEP, districts and schools must have at least 40 percent of their students directly certified by the state for free meals, without the use of a household application. Using administrative data, the state can directly certify (1) students whose households participate in public benefits programs, such as the Supplemental Nutritional Assistance Program (SNAP), Temporary Assistance for Needy Families (TANF), and Medicaid for children, and (2) students in other categorically eligible programs, such as homeless, runaway, migrant, foster care, and Head Start programs. In districts and schools that qualify for and participate in the CEP, parents of students no longer need to submit an application for FRPL, which was the approach that schools used to collect the student-level meal eligibility data before the CEP took effect. However, states still need the student-level FRPL data to satisfy federal and state school accountability requirements and to run their education aid formulas (if their formulas include FRPL as an input factor), as well as for many other data reporting purposes. Therefore, the Connecticut State Department of Education requires the CEP districts and schools to continue reporting each student's hypothetical eligibility for FRPL by using the following protocol. These districts and schools should report (1) the FRPL status of directly certified students as eligible for FRPL, (2) the FRPL status of returning students who are not directly certified the same as they were in the previous year, and (3) the FRPL status of new students who are not directly certified based on the "alternative income survey" that their parents are supposed to complete and return to schools. However, parents of new students have no personal incentive to complete the survey, since their children are already guaranteed to receive free meals in these CEP districts and schools. (See https://portal.ct.gov//media/SDE/Digest/cep memo and alt inc survey 08092014 2.pdf?la=en.) The resulting student-level hypothetical FRPL data are likely to be inaccurate, drawing serious concerns from state officials. When testifying before the Connecticut General Assembly's Appropriations Committee on March 6, 2019, the Connecticut State Department of Education officials highlighted "data integrity" issues in the student-level FRPL data (Connecticut School Finance Project 2019). The CEP was not available for Connecticut until FY 2015, when the program was rolled out nationwide. Therefore, the FRPL data used in this paper were not affected by the CEP, since they were collected in the FY 2009-2013 period. Nevertheless, I prefer the percentage of school-age children from families living in poverty, which was not affected by the CEP, to the FRPL measure, since one goal of this research is to recommend which cost factors the state should consider in the education aid formula to distribute future state grants.
} 
age children from families living in poverty, likely because for each district, the percentage of students eligible for FRPL is greater than the percentage of school-age children from families living in poverty. The income thresholds for free and reduced-price lunch are 130 percent and 185 percent, respectively, of the federal poverty guideline. The coefficients on other cost factors are similar to those in Column 1 (the preferred specification).

Second, I replace the dummy variable for enrollment of fewer than 2,000 students with the $\log$ of total enrollment and the square of the log of total enrollment in Column 3. In contrast to the dummy variable that estimates an average cost effect of small enrollments, the two continuous variables provide a deeper understanding of economies of scale. Both of the new variables are significant. Their signs indicate a U-shaped relationship between enrollment size and current spending per pupil. The most spending-efficient enrollment size for a district is about 8,350 students. One goal of this research is to recommend which cost factors the state should consider in the education aid formula; therefore, I prefer the dummy variable for enrollment of fewer than 2,000 students, because it is easier for policymakers to understand and implement, compared with the log of total enrollment and its square.

Third, I exclude potential outliers. In Column 4, I drop all pseudo regional K-12 districts in Column 4 to examine whether they are sufficiently different from other districts to drive the results. In Column 5, I exclude data from 2009 and 2010 to address the concerns that the two years are during or right after the Great Recession, a period that is significantly different from other parts of the sample period and may have affected different districts differently. Both sample changes have little impact on the cost factors.

Fourth, I use alternative measures of student test performance in Columns 6 through 14. In the preferred specification, I use the percentage of students who are at or above the proficiency 
level averaged across grades over three test subjects: math, reading, and writing. I replace it with the percentage of students who are at or above the proficiency level in each individual test subject in Columns 6 through 8. I do not include all three measures for the individual subjects in one regression because they are highly correlated with each other; the correlations among them are greater than 0.9 . As a result, I am unable to find three or more IVs that would separately identify each of the three performance measures if they were included in one regression. Next, in Columns 9 through 12, I use the average scale score in each test subject or scale score averaged over the three subjects to exploit the differences in education quality within districts with the same percentage of students reaching or exceeding the proficiency level. ${ }^{32}$ Then, in Columns 13 and 14 , I separate the high school students' test performance from the elementary and middle school students' test performance, because they take different tests - CMT for elementary and middle school students (grades 3 through 8) and CAPT for high school students (grade 10) —and averaging across all grades may hide heterogeneity across districts in high school education quality.

All of these alternative measures of student test performance are positive and significant, with coefficients similar to that on the performance-level variable in the preferred specification, with one exception. The percentage of students who reach or exceed the proficiency level in writing in Column 8 is not significant. More important, using these alternative measures of student test performance has almost no impact on the cost factors.

Fifth, I use non-test measures of education outcome in Columns 15 and 16. Because one may argue that an end product of $\mathrm{K}-12$ education is high school graduates, I include the four-year

\footnotetext{
${ }^{32}$ I also tried using log of average scale score, either in individual test subjects or averaged over three test subjects. These log variables are positive and significant. Using them does not affect the cost factors.
} 
high school graduation rate in Column $15 .{ }^{33}$ This variable is positive but not significant. The effect of high school graduation rates on school spending is not precisely estimated, because there are large measurement errors in those rates. The state gives districts and schools flexibility and multiple pathways to graduate high school students. Subject to the state's minimum requirements, districts have discretion in determining the number of required credits and the eligibility of credits counted toward high school graduation. The state also allows districts to award credits based on a demonstration of mastery. Therefore, the high school graduation rate reflects not only student performance but also a district's and school's choices and is therefore a noisy measure of education quality. ${ }^{34}$ Even though the high school graduation rate is insignificant, the cost factors in Column 15 have coefficients that are similar to those in the preferred specification, although some lose statistical significance.

In Column 16, I use the percentage of high school graduates pursuing higher education as another non-test education outcome measure. ${ }^{35}$ This variable is positive and highly significant. The cost factors are also positive and significant, with a magnitude similar to those in the preferred specification, except for the percentage of school-age children from families living in poverty.

Finally, I use a value-added measure of student test performance (also called growth measure) in Column 17 and then include it in conjunction with the percentage of students reaching

\footnotetext{
${ }^{33}$ The sample for Column 15 covers 118 districts that have no missing data on the four-year high school graduation rates. I also tried five-year and six-year high school graduation rates, which are available only from 2011 onward. The results using five-year and six-year rates are similar to those using the four-year rates.

${ }^{34}$ In the CCJEF v. Rell case, the superintendent of the Bridgeport School District acknowledged that the district could award a high school degree to a functionally illiterate student; the presiding state superior court judge called Connecticut's high school graduation requirements and rising high school graduation rates meaningless (Elizabeth A. Harris, "Judge, Citing Inequality, Orders Connecticut to Overhaul Its School System," New York Times, September 7 , 2016).

${ }^{35}$ The sample for Column 16 covers 114 districts that have no missing data on the percentage of high school graduates pursuing higher education. The sample period for Column 16 is 2009 through 2012. Year 2013 is dropped because as of that year, the state stopped counting participation in non-degree postsecondary programs as pursuing higher education.
} 
or exceeding the proficiency level in Column 18 and with average scale score in Column 19. To properly measure student growth over time, the state of Connecticut developed the CMT "vertical scales" for math and reading, which range from 200 to 700 (Connecticut State Department of Education 2009). Unlike the regular scale scores used in Columns 9 through 12, the vertical scales were constructed in such a way that the same vertical scale represents the same theoretical achievement level, regardless of grades and years in which students took the CMT. In other words, the vertical scales were designed to be comparable across grades and years. Therefore, the difference in the vertical scale between two grades for the same student indicates this student's growth over the corresponding period. For example, if a student received a vertical scale of 500 in the CMT grade-3 math test in 2008 and a vertical scale of 525 in the CMT grade- 4 math test in 2009, his or her growth in math from grade 3 in year 2008 to grade 4 in year 2009 is equal to 25 . Similarly, growth between grades and over years can be calculated for each school district as the difference in mean vertical scales of only matched students who took the CMT in both comparison grades and years. As a result, in each year and for each subject (math or reading), there are five measures of growth from one grade to the next higher grade for each school district, since students in six grades (grade 3 through grade 8) took the CMT each year. ${ }^{36}$ To simplify, I first calculate a weighted average of these five growth measures for each subject in each year for each district, using the number of matched students in the comparison grades as the weight. Then, I take a simple average of the two weighted averages between math and reading and use it as a summary measure of student growth in each year for each district. ${ }^{37}$

\footnotetext{
${ }^{36}$ These five growth measures include (1) growth from grade 3 in the previous year to grade 4 in the current year, (2) growth from grade 4 in the previous year to grade 5 in the current year, (3) growth from grade 5 in the previous year to grade 6 in the current year, (4) growth from grade 6 in the previous year to grade 7 in the current year, and (5) growth from grade 7 in the previous year to grade 8 in the current year.

${ }^{37}$ The data sample used in Columns 17 through 19 includes $113 \mathrm{~K}-12$ districts that have no missing growth measures during the 2009-2013 period.
} 
While this growth measure of student performance has some advantages over the level measure of student performance, it also has several limitations. First, how accurately it measures student growth may be questionable. Kane and Staiger (2002) show that in general, value-added measures often contain a considerable amount of data noise, especially for small school districts. Second, growth in writing was not measured, since Connecticut did not develop vertical scales for the writing tests. Third, growth in high school students' performance was not measured. Because Connecticut high school students took the CAPT only in grade 10, no comparisons could be made between different high school grades. The state also did not develop vertical scales to link CAPT performance to CMT performance. Therefore, it is impossible to measure the growth from grade 8 to grade 10. Fourth, the growth concept cannot be applied to non-test student performance, such as high school graduation and college entrance. These achievements are one-time events for individual students and, unlike grade-level tests, cannot repeat over time. In addition, it is harder for policymakers to interpret the change in vertical scales between grades than to make year-overyear comparisons in the percentage of students reaching or exceeding the proficiency level.

Given these limitations, the Connecticut State Department of Education (2009) explicitly expresses that the growth measure based on vertical scales is not intended to replace the percentage of students reaching or exceeding the proficiency level, which is a more widely accepted and used measure of student performance. ${ }^{38}$ Instead, the growth measure should be considered complementary to the proficiency-level measure. In my sample, the average growth is positively,

\footnotetext{
${ }^{38}$ My understanding, based on communications with the Connecticut State Department of Education and reading relevant laws and documents, is that the state published the CMT vertical scales and the resulting growth measures for informational purposes and did not use them for accountability. In contrast, the state heavily relied on the percentage of students reaching or exceeding the proficiency level to identify low-performing schools and school districts.
} 
but weakly, correlated with the percentage of students reaching or exceeding the proficiency level and with average scale score, with simple correlations of 0.24 and 0.26 , respectively.

Columns 17 through 19 show that taking into account the growth measure has little impact on the cost variables. The cost coefficients in these columns are similar to those in the preferred specification. The average growth is not significant though, possibly due to the limitations discussed above.

\section{Cost Index}

The effects of various cost factors on school spending can be aggregated into a composite index, commonly known as the cost index. It compares a district's predicted spending per pupil to that of a hypothetical average district while all other variables in the estimation equation are held constant. ${ }^{39}$ The hypothetical average district is defined as a district with the enrollment-weighted statewide average values of the cost factors and all other variables. Because all other variables are held constant, they are cancelled out from the numerator and denominator of the cost index and thus do not affect the calculations of the index. In other words, the cost index depends on only the cost factors. Thus, school districts are not rewarded for having a lower efficiency, because a lower efficiency would not increase the cost index. Also, school districts are not penalized for having a higher efficiency, because a higher efficiency would not decrease the cost index.$^{40}$ In mathematical terms,

\footnotetext{
${ }^{39}$ A common practice in the literature is to set the values of all other variables to be the enrollment-weighted statewide average in calculating the cost index. But those variables can actually be set at any fixed values, since they are cancelled out from both the numerator and the denominator and do not affect the cost index.

${ }^{40}$ How to increase school efficiency is beyond the scope of this paper. However, it is an important issue for the state that deserves a separate study.
} 


$$
C I_{i t}=\frac{\widehat{E_{l t}}}{\widehat{E_{a t}}}=e^{\alpha\left(C_{i t}-C_{a t}\right)},
$$

where $C I$ is the cost index, $\hat{E}$ is the predicted spending, $C$ is the cost factors, $\alpha$ is the estimated coefficients on the cost factors $C, i$ is an index for districts, $t$ is an index for years, and $a$ is an indicator for the hypothetical average district.

By construction, the cost index for the hypothetical average district is equal to 1 . If a district's cost index is greater than 1 , it means that the district has higher costs per pupil than the average district does, when education outcome and efficiency are held constant across districts. For example, a cost index of 1.1 means that a district's costs per pupil are 10 percent higher than those of the average district. In contrast, a cost index of 0.9 means that a district's costs per pupil are 10 percent lower than those of the average district. I first calculate the cost index for each district in each year, and then I take the five-year average of each district's cost index to reduce the influence of a large one-year change in the cost factors. ${ }^{41}$

There are large disparities in the cost index across Connecticut districts. It ranges from 0.82 for the Wilton School District (in wealthy Fairfield County) to 1.47 for the Hartford School District (the state's capital city). In other words, the maximum value of the cost index is almost 1.8 times the minimum value of the cost index..$^{42}$ The ratio of the $90^{\text {th }}$ percentile in the cost index distribution to the $10^{\text {th }}$ percentile and the ratio of the $80^{\text {th }}$ percentile to the $20^{\text {th }}$ percentile are about 1.6 and 1.3 ,

\footnotetext{
${ }^{41} \mathrm{I}$ am able to calculate the cost index for $119 \mathrm{~K}-12$ districts, including two pseudo regional $\mathrm{K}-12$ districts that are excluded from regressions due to missing data on student test performance. However, I do not need their actual test performance measures to calculate their cost indices.

${ }^{42}$ The maximum-to-minimum ratio for Connecticut lies within the range of the maximum-to-minimum ratios for other states estimated in previous studies and is near the lower end of this range. See Appendix Table 3 for a review of the maximum-to-minimum ratios in previous cost function studies.
} 
respectively. ${ }^{43}$ In addition, about 38 percent of Connecticut's public school students are enrolled in districts where the cost index is greater than 1 .

The cost index value is not geographically evenly distributed (Figure 1). The highest cost indices are concentrated among the largest school districts that are also poor and urban. The wealthy suburbs tend to have the lowest cost indices. In particular, Fairfield County, which is in the southwestern corner of the state and near New York City, has a large cluster of the lowest-cost school districts.

Table 4 shows the distribution of the cost index by some district characteristics. Districts with the largest enrollments (that is, those in the fifth enrollment quintile), the highest school-agechild-poverty rates (those in the fifth poverty quintile), or the least amount of property wealth per pupil (those in the first property wealth quintile) tend to have the highest average cost index across the state. This is because such districts, on average, have the highest percentage of school-age children from families living in poverty and the highest percentage of students living in singleparent or non-family households. The smallest districts (that is, those in the first enrollment quintile) have the second-highest average cost index, partly because each has an enrollment of fewer than 2,000 students. In addition, the highest-cost districts (those in the fifth cost index quintile) have an average cost index of 1.25 and disproportionally are large districts. The highest cost index quintile includes 20 percent of Connecticut's districts, but close to 30 percent of the state's public school students.

\section{Cost-adjusted Spending}

\footnotetext{
${ }^{43}$ These percentiles are enrollment-weighted.
} 
Because costs are not directly observable, but spending is, policymakers and practitioners often focus on spending disparities. However, a comparison of spending among districts that does not take cost differentials into account provides only a partial, and sometimes misleading, picture of funding equity.

Following Baker et al. (2018), I calculate cost-adjusted spending that considers both spending and costs:

$$
C E_{i t}=\frac{E_{i t}}{C I_{i t}},
$$

where $C E$ is cost-adjusted spending per pupil, $E$ is current spending per pupil, and $C I$ is the cost index. While two districts with the same current spending per pupil can have different cost indices, the one with the higher cost index will have lower cost-adjusted spending. Therefore, using costadjusted spending can reveal more disparities across districts, compared with using unadjusted spending. Indeed, Table 5 shows that compared with unadjusted spending, cost-adjusted spending has a higher value in each of the six inequality measures.

Connecticut has large disparities in cost-adjusted spending. Averaged over the five-year 2009-2013 period, cost-adjusted spending ranges from $\$ 10,000$ per pupil for the New Britain School District (one of the largest and poorest cities in Connecticut) to nearly $\$ 23,300$ per pupil for the Weston School District (a wealthy town in Fairfield County). Table 6 shows that the districts with the largest enrollments, the highest school-age-child-poverty rates, or the least amount of property wealth, on average, have the lowest cost-adjusted spending in the state. This is not because their unadjusted spending is too low. In fact, their unadjusted spending, on average, 
is either the highest or second-highest among the five quintiles. ${ }^{44}$ In contrast, their cost index, on average, is the highest in the state. Furthermore, districts in the highest cost index quintile have the lowest average cost-adjusted spending, despite having the highest average spending per pupil. In other words, these districts' spending per pupil is relatively high, but not high enough to compensate for their high costs. These results suggest that costs play a larger role than spending in driving the disparities in cost-adjusted spending in Connecticut.

\section{Spending-to-cost Ratio}

While cost-adjusted spending is a powerful tool for describing spending equity, on its own it is insufficient for examining spending adequacy. This is because the cost index, and therefore costadjusted spending, is not defined according to any specific student performance level. Following Baker et al. (2018), I calculate the spending-to-cost ratio in order to assess whether a district's spending is adequate for achieving a common target level of student performance. The spendingto-cost ratio is defined as:

$$
S C_{i t}=\frac{E_{i t}}{\widehat{E_{i t}}\left(S_{t}\right)}=\frac{E_{i t}}{e^{\left(\alpha C_{i t}+\beta S_{t}+\gamma O_{t}\right)}}
$$

where $S C$ is the spending-to-cost ratio, $E$ is actual spending per pupil, $\hat{E}(S)$ is the predicted cost to achieve a specific student performance level $S$ that is uniform across the state, $C$ is the cost factors, $\alpha$ is the estimated coefficients on the $\operatorname{cost}$ factors $C, \beta$ is the estimated coefficient on student performance, $O$ is all other variables in the estimation equation, and $\gamma$ is the estimated coefficients

\footnotetext{
${ }^{44}$ Appendix Table 2 shows the disaggregated categories of unadjusted current spending by district characteristics. Districts with the largest enrollments, the highest school-age-child-poverty rates, or the least amount of property wealth, on average, have the highest or second-highest dollar amounts of current spending on instruction. The dollar amounts of their spending on support services and other programs, on average, are similar to those of districts in other quintiles and are never the highest.
} 
on other variables $O$. In the literature, other variables $O$ are often set at the enrollment-weighted statewide average values. ${ }^{45}$ When this is the case, the predicted cost $\hat{E}(S)$ measures how much each district must spend to achieve the common student performance target $(S)$, given its cost factors $(C)$, if it operates at an average efficiency level. ${ }^{46}$

The higher the performance target is, the higher the predicted cost is. However, the relationship between the two is nonlinear. A 1 percentage point increase in the student performance target results in a dollar-amount increase in the predicted cost that is larger for high-cost districts than it is for low-cost districts, because the predicted cost depends on the interaction of the performance target with the cost factors.

The student performance target is a policy variable for the state. For illustration purpose, I calculate each district's spending-to-cost ratio at four different performance levels: the statewide average for students reaching or exceeding the proficiency level, 90 percent of students reaching or exceeding it, 95 percent, and 100 percent. The enrollment-weighted statewide average percentage of students reaching or exceeding the proficiency level was about 83 percent for the 2009-2013 period. The federal No Child Left Behind (NCLB) Act required that 100 percent of each state's public school students be at or above the proficiency level in state standardized tests

\footnotetext{
${ }^{45}$ The state could potentially use efficiency-related variables as a policy lever to influence the predicted cost measure and then ultimately affect state funding responsibility for schools. Instead of setting $O_{i t}$ at the statewide average values in equation (8), the state could first calculate $r O_{i t}$ (that is, the contribution from efficiency-related variables to the predicted cost) using each district's actual values of $O_{i t}$, rank the values of $r O_{i t}$ from low to high, choose a value from this distribution, and then assign this chosen value of $r O_{i t}$ to every district in calculating its predicted costs. If policymakers want to decrease state funding responsibility for schools, they could choose a smaller value, for example, the value at the 25th percentile of the distribution of $r O_{i t}$, which means that the state assumes that every district should operate at the top 25th percentile efficiency level instead of the statewide average efficiency level, which will result in a lower predicted cost measure for every school district. Nevertheless, this does not change the landscape of cost disparities across school districts, because the cost index is calculated under the assumption that all districts operate at the same efficiency level and is therefore independent of efficiency.

${ }^{46}$ Spending the same amount of money as the predicted cost does not guarantee that a school district will achieve the student test performance target on which the predicted cost is based. If the district operates at an efficiency level that is lower than the assumed statewide average, it will not effectively help students learn and will not achieve the performance target.
} 
by fiscal year 2014. But no states met the requirement by the deadline. For simplicity, this paper shows the spending-to-cost ratio calculated at 90 percent of students reaching or exceeding the proficiency level. Spending-to-cost ratios at the three other performance levels (average, 95 percent, and 100 percent) are available upon request.

Unlike cost-adjusted spending, the spending-to-cost ratio can be used to examine not only equity, but also adequacy in district spending. If a district's spending-to-cost ratio is less than 1 , it means that the district's spending is not adequate for paying the education costs required to reach the selected performance target. For example, a spending-to-cost ratio of 0.9 indicates that a district spends 10 percent less than its predicted cost required to achieve the student performance target level.

By this definition, the education spending for a large share of Connecticut's public school students is inadequate. If the performance target is assumed to call for 90 percent of students to reach or exceed the proficiency level in each district, then more than 74 percent of public school students in Connecticut were enrolled in districts where the spending-to-cost ratio was less than 1 during the 2009-2013 period. If the performance target is raised to 95 percent and 100 percent of students reaching or achieving the proficiency level, then 82 percent and 89 percent of students, respectively, attended districts where spending-to-cost ratios were less than $1 .{ }^{47}$

There are large disparities in the spending-to-cost ratio across districts. ${ }^{48}$ Assuming a performance target of 90 percent of students reaching of exceeding the proficiency level, the five-

\footnotetext{
${ }^{47}$ If the performance target is the enrollment-weighted statewide average percentage of students who are at or above the proficiency level, then about 52 percent of students were enrolled in school districts with spending-to-cost ratios that were less than 1 .

48 The spending-to-cost ratio and cost-adjusted spending are mathematically linked to each other. First, $\widehat{E_{l t}}(S)=$ $C I_{i t} \times \hat{E}_{a t}(S)$, where $\hat{E}_{a t}(S)$ is the predicted cost for the hypothetical average district to reach the performance target
} 
year average spending-to-cost ratio ranges from 0.61 for the New Britain School District to 1.46 for the Weston School District.

In terms of the spatial distribution of the spending-to-cost ratio, spending exceeded predicted costs in most of Fairfield County, several coastal districts, and some inland suburban districts (Figure 2). However, in the majority of Connecticut school districts, spending was inadequate for achieving the target of 90 percent of students reaching or exceeding the proficiency level.

In addition, Table 7 shows that districts with the largest enrollments, the highest schoolage-child-poverty rates, or the least amount of property wealth, on average, have the lowest spending-to-cost ratios. In contrast, districts with the lowest school-age-child-poverty rates or the greatest amount of property wealth, on average, have the highest spending-to-cost ratios, and they are all greater than $1 .^{49}$

\section{Spending Gap}

It is important that the state takes both spending and costs into consideration when enforcing school accountability policies. Figure 3 shows that when cost differentials are ignored, there is no relationship between student test performance and current spending per pupil among the school districts. Thus, one may incorrectly infer that money does not matter, and therefore, increasing school spending will not lead to an improvement in student performance.

$S$ at the average efficiency level. Then, $S C_{i t}=\frac{E_{i t}}{\widehat{E_{i t}}(S)}=\left(\frac{E_{i t}}{C I_{i t}}\right) \times\left(\frac{1}{\widehat{E_{a t}}(S)}\right)=C S_{i t} \times\left(\frac{1}{\widehat{E_{a t}}(S)}\right)$. Because $\frac{1}{\widehat{E_{a t}}(S)}$ is a constant in any given year, the spending-to-cost ratio $S C_{i t}$ and cost-adjusted spending $C S_{i t}$ would have the same value of such inequality measures as $\frac{\text { maxmimum }}{\text { minimum }}, \frac{90^{\text {th }} \text { Percentile }}{10^{\text {th }} \text { Percentile }}, \frac{80^{\text {th }} \text { Percentile }}{20^{\text {th }} \text { Percentile }}$, and the Gini coefficient. Also for this reason, Tables 6 and 7 show the same disparity pattern.

49 These districts tend to have a sizeable enrollment that lands them in the second-highest enrollment quintile. 
There are indeed negative consequences for student performance when a district's spending is inadequate relative to the predicted cost required to achieve the common student performance target level. Figure 4 compares the student performance gap with the spending gap per pupil across Connecticut school districts in the 2009-2013 period. The student performance gap is defined as the difference between the state's student performance target and a district's actual student performance level. For illustration purposes, the state's performance target is set at 90 percent of students reaching or exceeding the proficiency level in every district. The spending gap is defined as the difference between a district's predicted cost for achieving this performance target level and its actual current spending per pupil. A higher spending gap indicates more severe spending inadequacy.

Figure 4 shows that there is a significant positive relationship between the spending gap and the student performance gap, regardless of whether it is estimated using a univariate linear regression or kernel-weighted local-mean smoothing (a non-parametric approach). When a district's spending is more severely inadequate relative to the predicted cost, its student performance level tends to fall further below the common target.

Therefore, many districts need additional spending to achieve a common student performance target level. This paper defines the additional spending that a district needs as equal to its spending gap when the gap is positive. However, when a district has a negative spending gap, which means that it already spends more money than the predicted cost, its needed additional spending is equal to zero. This paper does not allow the needed additional spending to be negative, because it is unlikely that the state will want to force districts to reduce their spending. Some districts have legitimate reasons for spending above the predicted cost. For example, they may aim at a performance level that is higher than the common target, or they may spend more on untested 
subjects in response to parents' demands. These districts should not be penalized and forced to reduce their expenditures.

Estimates in this paper show that Connecticut school districts need a large amount of additional spending to close the gaps between student performance and the common target. For example, for 90 percent of students to have reached or exceeded the proficiency level, Connecticut school districts as a whole would have needed to spend an additional \$1.34 billion in fiscal year 2013, which represents a 17.6 percent increase from the actual statewide school spending of $\$ 7.63$ billion that year. Furthermore, the amount of additional spending needed increases with the state's performance target, since a higher performance target results in a higher predicted cost. For instance, Connecticut school districts as a whole would have had to spend an additional $\$ 1.70$ billion and $\$ 2.12$ billion —a 22.3 percent and 27.8 percent increase, respectively, from the actual fiscal year 2013 statewide school spending — to have achieved a performance target of 95 percent of students reaching or exceeding the proficiency level and 100 percent, respectively. ${ }^{50}$

While there is widespread need for additional school spending, the amount varies significantly across districts. Table 8 shows that no district quintile requires zero additional spending. In other words, the need for additional spending is not unique to particular types of school districts. However, districts with the largest enrollments, the highest school-age-childpoverty rates, the least amount of property wealth, or the highest cost indices, on average, need the highest additional spending per pupil and the largest increases from the actual current spending per pupil. In contrast, districts with the lowest school-age-child-poverty rates, the greatest amount

\footnotetext{
50 The statewide additional spending needed to achieve the enrollment-weighted statewide average student performance level in fiscal year 2013 (that is, about 83 percent of students reaching or exceeding the proficiency level) would have been $\$ 940$ million, or 12.3 percent of the actual statewide school spending that year.
} 
of property wealth, or the lowest cost indices, on average, need the lowest additional spending per pupil and the smallest increases from the actual current spending per pupil.

\section{Conclusion and Policy Discussions}

In estimating the cost function of Connecticut public $\mathrm{K}-12$ education, this paper finds that when student performance and district efficiency are held constant, school districts have to spend more if they have a higher school-age-child-poverty rate, a higher percentage of students living in singleparent or non-family households, or an enrollment smaller than 2,000 students, or if they are a regional school district. There are large disparities across districts in the cost index and in costadjusted spending. Districts with the largest enrollments, the highest school-age-child-poverty rates, or the least amount of property wealth, on average, have the highest cost indices and the lowest cost-adjusted spending.

The analysis shows that a large share of Connecticut's public school students are enrolled in school districts where spending is inadequate relative to the predicted cost for achieving a common student performance target. Inadequate school spending is implied to contribute to student underperformance relative to the common target.

Therefore, this paper suggests that many districts need to increase their spending to meet their predicted costs and close the gaps between their student performance levels and the common target. While the need for additional spending is widespread, districts with the highest cost indices, on average, require the most additional spending per pupil.

Meeting these needs for additional spending would likely require more state aid. School districts are less likely to seek additional revenue from local property taxes for two reasons. First, Connecticut districts already receive a significantly higher share of total revenue from local 
sources compared with US districts as a whole (Table 1). Increasing property taxes would make the locally sourced share of districts' total revenue even higher and less sustainable. Second, districts that need the highest amount of additional spending per pupil are exactly the ones that have the lowest property tax bases and the highest property tax rates in the state. Therefore, it does not seem feasible for these property-poor cities and towns to fund additional school spending by substantially raising property taxes.

More importantly, to better address spending inequity and inadequacy, the state may consider adopting the predicted-cost measure that this paper develops as the basis of a new, scientifically grounded formula. ${ }^{51}$ Because the predicted cost is calculated based on cost factors and their regression coefficients, which are derived from rigorous data analysis, it is more rational and defensible than the foundation amount and the "need-student" weights that are arbitrarily determined and used in Connecticut's current formula. When two school districts have the same ability to raise local revenues, an equitable and adequate formula should allocate more state aid to the district with a higher predicted cost per pupil. Using such a new formula will enable the state to target state aid more effectively to districts that need more help.

\footnotetext{
${ }^{51}$ Using Connecticut as a case study, Zhao (2020) shows how to design a state education aid formula that is equitable,
} adequate, and politically feasible. 


\section{References}

Andrews, Matthew, William Duncombe, and John Yinger. 2002. "Revisiting Economies of Size in American Education: Are We Any Closer to a Consensus?" Economics of Education Review 21(3): 245-262.

Baker, Bruce. 2009. "Within-District Resource Allocation and the Marginal Costs of Providing Equal Educational Opportunity: Evidence from Texas and Ohio." Education Policy Analysis Archives 17(3).

Baker, Bruce, Mark Weber, Ajay Srikanth, Robert Kim, and Michael Atzbi. 2018. "The Real Shame of the Nation: The Causes and Consequences of Interstate Inequity in Public School Investments." Policy Report. Newark, NJ: Education Law Center of New Jersey \& Rutgers Graduate School of Education.

Card, David, and A. Abigail Payne. 2002. "School Finance Reform, the Distribution of School Spending, and the Distribution of Student Test Scores." Journal of Public Economics 83(1): 49-82.

Chaudhary, Latika. 2009. "Education Inputs, Student Performance and School Finance Reform in Michigan." Economics of Education Review 28(1): 90-98.

Connecticut School Finance Project. 2019. "School Finance 101: An Introduction to How Public Schools Are Funded in Connecticut." Presentation Updated March 21, 2019. New Haven, CT: Connecticut School Finance Project.

Connecticut State Department of Education. 2009. "Connecticut Mastery Test Fourth Generation Data Analysis Guide." New Haven, CT: Connecticut State Department of Education.

Deke, John. 2003. "A Study of the Impact of Public School Spending on Postsecondary Educational Attainment Using Statewide School District Refinancing in Kansas." Economics of Education Review 22(3): 275-284.

Downes, Thomas, and Thomas Pogue. 1994. "Adjusting School Aid Formulas for the Higher Cost of Educating Disadvantaged Students." National Tax Journal 47(1): 89-110.

Duncombe, William. 2002. "Estimating the Cost of an Adequate Education in New York." Working Paper 44. Syracuse, NY: Syracuse University, Center for Policy Research.

Duncombe, William. 2006. "Responding to the Charge of Alchemy: Strategies for Evaluating the Reliability and Validity of Costing-out Research." Journal of Education Finance 32(2): $137-169$.

Duncombe, William. 2007. "Estimating the Cost of Meeting Student Performance Standards in the St. Louis Public Schools." Report Prepared for the St. Louis Board of Education. Syracuse, NY: Syracuse University, Center for Policy Research. 
Duncombe, William, Anna Lukemeyer, and John Yinger. 2003. "Financing an Adequate Education: A Case Study of New York." In Developments in School Finance 2001-2002, 129-153. Washington, DC: U.S. Department of Education.

Duncombe, William, John Ruggiero, and John Yinger. 1996. "Alternative Approaches to Measuring the Cost of Education." In Holding Schools Accountable: Performance-Based Reform in Education, ed. H.F. Ladd, 327-356, Washington, DC: Brookings Institution.

Duncombe, William, and John Yinger. 1997. "Why Is It So Hard to Help Central City Schools?" Journal of Policy Analysis and Management 16(1): 85-113.

Duncombe, William, and John Yinger. 1998. "School Finance Reform: Aid Formulas and Equity Objectives." National Tax Journal 51(2): 239-262.

Duncombe, William, and John Yinger. 1999. "Performance Standards and Education Cost Indexes: You Can't Have One without the Other." In Equity and Adequacy in Education Finance: Issues and Perspectives, ed. Helen F. Ladd, Rosemary Chalk, and Janet S. Hansen, 260-297, Washington, DC: National Academies Press.

Duncombe, William, and John Yinger. 2000. "Financing Higher Student Performance Standards: The Case of New York State." Economics of Education Review 19(4): 363-386.

Duncombe, William, and John Yinger. 2005a. "Estimating the Costs of Meeting Student Performance Outcomes Adopted by the Kansas State Board of Education." Report Prepared for the Kansas Legislative Division of Post Audit. Syracuse, NY: Syracuse University, Center for Policy Research.

Duncombe, William, and John Yinger. 2005b. "How Much More Does a Disadvantaged Student Cost?" Economics of Education Review 24(5): 513-532.

Duncombe, William, and John Yinger. 2006. "Understanding the Incentives in California's Education Finance System." Report Prepared for the Getting Down to Facts Project. Syracuse, NY: Syracuse University, Center for Policy Research.

Duncombe, William, and John Yinger. 2007. "Does School District Consolidation Cut Costs?" Education Finance and Policy 2(4): 341-375.

Duncombe, William, and John Yinger. 2011a. "Are Education Cost Functions Ready for Prime Time? An Examination of Their Validity and Reliability." Peabody Journal of Education 86(1): 28-57.

Duncombe, William, and John Yinger. 2011b. "Making Do: State Constraints and Local Responses in California's Education Finance System." International Tax and Public Finance 18(3): 337-368.

Elliot, Marta. 1998. "School Finance and Opportunities to Learn: Does Money Well Spent Enhance Students' Achievement?" Sociology of Education 71(3): 223-245. 
Fletcher, Deborah. 2006. "It Takes a Village? Intergenerational Conflict and Cooperation in Education Expenditures." Unpublished Paper. Oxford, OH: Miami University.

Gigliotti, Philip, and Lucy C. Sorensen. 2018. "Education Resources and Student Achievement: Evidence from the Save Harmless Provision in New York State." Economics of Education Review 66: 167-182.

Gronberg, Timothy J., Dennis W. Jansen, and Lori L. Taylor. 2011. "The Adequacy of Educational Cost Functions: Lessons from Texas." Peabody Journal of Education 86(1): $3-27$.

Gronberg, Timothy J., Dennis W. Jansen, Lori L. Taylor, and Kevin Booker. 2004. "School Outcomes and School Costs: The Cost Function Approach." Draft Paper. College Station, TX: Texas A\&M University.

Guryan, Jonathan. 2001. "Does Money Matter? Regression-Discontinuity Estimates from Education Finance Reform in Massachusetts." NBER Working Paper 8269. Cambridge, MA: National Bureau of Economic Research.

Hilber, Christian A. L., and Christopher Mayer. 2009. "Why do Households without Children Support Local Public Schools? Linking House Price Capitalization to School Spending." Journal of Urban Economics 65(1): 74-90.

Hoxby, Caroline M. 2000. "Does Competition among Public Schools Benefit Students and Taxpayers?" The American Economic Review 90(5): 1209-1238.

Hyman, Joshua. 2017. "Does Money Matter in the Long Run? Effects of School Spending on Educational Attainment." American Economic Journal: Economic Policy 9(4): 256-280.

Imazeki, Jennifer. 2001. "Grade-dependent Costs of Education: Evidence from Illinois." Draft Paper. San Diego, CA: San Diego State University.

Imazeki, Jennifer. 2008. "Assessing the Costs of Adequacy in California Public Schools: A Cost Function Approach." Education Finance and Policy 3(1): 90-108.

Imazeki, Jennifer, and Andrew Reschovsky. 2003. "Financing Adequate Education in Rural Settings." Journal of Education Finance 29(2): 137-156.

Imazeki, Jennifer, and Andrew Reschovsky. 2004. "Is No Child Left Behind an Un (or Under) funded Federal Mandate? Evidence from Texas." National Tax Journal 57(3): 571-588.

Imazeki, Jennifer, and Andrew Reschovsky. 2005. "Assessing the Use of Econometric Analysis in Estimating the Costs of Meeting State Education Accountability Standards: Lessons from Texas." Peabody Journal of Education 80(3): 96-125.

Imazeki, Jennifer, and Andrew Reschovsky. 2006. "Does No Child Left Behind Place a Fiscal Burden on States? Evidence from Texas." Education Finance and Policy 1(2): 217-246. 
Jackson, C. Kirabo, Rucker C. Johnson, and Claudia Persico. 2016. "The Effects of School Spending on Educational and Economic Outcomes: Evidence from School Finance Reforms." Quarterly Journal of Economics 131(1): 157-218.

Kane, Thomas J., and Douglas O. Staiger. 2002. "The Promise and Pitfalls of Using Imprecise School Accountability Measures." Journal of Economic Perspectives 16(4): 91-114.

Kinnucan, Henry W., Yuqing Zheng, and Gerald Brehmer. 2006. "State Aid and Student Performance: A Supply-Demand Analysis." Education Economics 14(4): 487-509.

Lafortune, Julien, Jesse Rothstein, and Diane Whitmore Schanzenbach. 2018. "School Finance Reform and the Distribution of Student Achievement." American Economic Journal: Applied Economics 10(2): 1-26.

Martorell, Paco, Kevin Stange, and Issac McFarlin Jr. 2016. "Investing in Schools: Capital Lending, Facility Conditions, and Student Achievement." Journal of Public Economics 140(C): 13-29.

Moran, John D., Marybeth Sullivan, Sarah Bourne, and Alan Shepard. 2016. "Education Cost Sharing Grants." Research Report 2016-R-0167. Hartford, CT: Office of Fiscal Analysis and Office of Legislative Research.

Nguyen-Hoang, Phuong, and John Yinger. 2014. "Education Finance Reform, Local Behavior, and Student Performance in Massachusetts." Journal of Education Finance 39(4): $297-332$.

Reschovsky, Andrew, and Jennifer Imazeki. 2003. "Let No Child Be Left Behind: Determining the Cost of Improving Student Performance." Public Finance Review 31(3): 263-290.

Roy, Joydeep. 2011. "Impact of School Finance Reform on Resource Equalization and Academic Performance: Evidence from Michigan." Education Finance and Policy 6(2): 137167.

Sullivan, Marybeth. 2018. "Education Cost Sharing Grant Formula." Issue Brief 2018-R0295. Hartford, CT: Office of Legislative Research.

Zhao, Bo. 2020. "How to Design a State Education Aid Formula That Is Equitable, Adequate, and Politically Feasible: The Case of Connecticut." Research Department Working Papers. Boston, MA: Federal Reserve Bank of Boston. 
Table 1. Comparing Public K-12 Education Systems between Connecticut and Other States FY 2017

\begin{tabular}{|c|c|c|c|c|c|c|c|c|c|c|}
\hline & \multirow{2}{*}{$\mathrm{CT}$} & \multicolumn{5}{|c|}{ Other New England States } & \multicolumn{3}{|c|}{ Mid-Atlantic States } & \multirow{2}{*}{ US } \\
\hline & & $\mathrm{ME}$ & MA & $\mathrm{NH}$ & RI & $\mathrm{VT}$ & NJ & NY & $\mathrm{PA}$ & \\
\hline \multicolumn{11}{|l|}{ Public School Student Population } \\
\hline Enrollment (Thousands of Students) & 535.12 & 180.51 & 964.51 & 180.89 & 142.15 & 88.43 & $1,410.42$ & $2,729.78$ & $1,727.50$ & 991.92 \\
\hline Percentage of Students Who Are Black & 12.84 & 3.46 & 8.91 & 1.98 & 8.45 & 2.01 & 15.85 & 17.38 & 14.79 & 15.31 \\
\hline Percentage of Students Who Are Hispanic & 24.01 & 2.12 & 19.33 & 5.17 & 24.69 & 1.88 & 27.61 & 26.51 & 10.98 & 26.32 \\
\hline \multicolumn{11}{|l|}{ Fiscal Indicators } \\
\hline Current Spending per Pupil (Thousands of Dollars) & 19.32 & 13.69 & 16.20 & 15.68 & 15.94 & 18.29 & 18.92 & 23.09 & 15.80 & 12.20 \\
\hline Current Spending as Percentage of Personal Income & 39.61 & 42.28 & 36.05 & 37.01 & 41.89 & 53.31 & 48.59 & 52.36 & 40.96 & 37.46 \\
\hline Percentage of Total Revenue from Federal Sources & 4.29 & 6.66 & 4.28 & 5.40 & 7.25 & 6.10 & 4.10 & 5.26 & 6.42 & 7.97 \\
\hline Percentage of Total Revenue from State Sources & 38.01 & 38.34 & 38.73 & 32.13 & 40.52 & 90.31 & 40.95 & 40.84 & 38.67 & 47.12 \\
\hline Percentage of Total Revenue from Local Sources & 57.70 & 55.00 & 56.98 & 62.47 & 52.23 & 3.59 & 54.95 & 53.90 & 54.90 & 44.91 \\
\hline \multicolumn{11}{|l|}{ Student Performance in National Assessment of Educational Progress (NAEP) } \\
\hline Percentage of Grade-4 Students Reaching or Exceeding Proficiency in Math & 39.92 & 40.24 & 52.91 & 47.71 & 38.64 & 42.21 & 49.93 & 35.47 & 43.63 & 39.54 \\
\hline Percentage of Grade- 4 Students Reaching or Exceeding Proficiency in Reading & 42.73 & 36.37 & 50.82 & 43.03 & 38.73 & 42.93 & 48.63 & 35.96 & 40.18 & 35.44 \\
\hline Percentage of Grade-8 Students Reaching or Exceeding Proficiency in Math & 36.22 & 35.99 & 49.69 & 45.41 & 30.23 & 39.37 & 43.76 & 33.85 & 38.13 & 33.43 \\
\hline Percentage of Grade-8 Students Reaching or Exceeding Proficiency in Reading & 43.76 & 39.05 & 49.32 & 45.05 & 37.42 & 44.77 & 46.65 & 34.16 & 39.99 & 34.74 \\
\hline
\end{tabular}

Sources: National Center for Educational Statistics and US Census Bureau's Annual Survey of School System Finances

Note: Enrollment for the United States is a simple average of enrollments in 50 states and Washington, DC 
Table 2. Regression Results from the Preferred Specification

2009-2013

\begin{tabular}{|c|c|c|}
\hline & \multicolumn{2}{|l|}{ Dependent Variables } \\
\hline & $\begin{array}{c}\text { Percentage of Students Reaching or Exceeding } \\
\text { Proficiency in Math, Reading, and Writing } \\
\text { (First Stage) }\end{array}$ & $\begin{array}{l}\text { Log of Current } \\
\text { Spending per Pupil } \\
\text { (Second Stage) }\end{array}$ \\
\hline \multicolumn{3}{|l|}{ Instrumental Variables: } \\
\hline Neighbor Districts' Percentage of Property Tax Base from Businesses & $\begin{array}{c}-1.093^{* * *} \\
(0.353)\end{array}$ & \\
\hline Neighbor Districts' Percentage of Adults without a High School Degree & $\begin{array}{c}0.888^{*} \\
(0.520)\end{array}$ & \\
\hline \multicolumn{3}{|l|}{ Education Outcome: } \\
\hline Percentage of Students Reaching or Exceeding Proficiency in Math, Reading, and Writing & & $\begin{array}{c}0.010^{*} \\
(0.005)\end{array}$ \\
\hline \multicolumn{3}{|l|}{ Cost Factors: } \\
\hline Percentage of School-age Children (Aged 5-17) from Families Living in Poverty & $\begin{array}{c}-0.734^{* * *} \\
(0.156)\end{array}$ & $\begin{array}{c}0.012^{* *} \\
(0.005)\end{array}$ \\
\hline Percentage of Children Enrolled in Public Schools Living in Single-parent or Non-family Households & $\begin{array}{c}-0.122^{* * *} \\
(0.038)\end{array}$ & $\begin{array}{c}0.003^{*} \\
(0.002)\end{array}$ \\
\hline Dummy for Enrollment $<2,000$ & $\begin{array}{c}-0.962 \\
(0.694)\end{array}$ & $\begin{array}{l}0.072^{* * *} \\
(0.022)\end{array}$ \\
\hline Dummy for Regional School District & $\begin{array}{c}-0.480 \\
(0.466)\end{array}$ & $\begin{array}{l}0.077^{\text {*** }} \\
(0.019)\end{array}$ \\
\hline \multicolumn{3}{|l|}{ Efficiency Variables: } \\
\hline Log of Real ENGL per Pupil & $\begin{array}{c}-0.136 \\
(1.021)\end{array}$ & $\begin{array}{c}0.221^{* * *} \\
(0.025)\end{array}$ \\
\hline Log of Median Household Income & $\begin{array}{c}-2.705 \\
(2.792)\end{array}$ & $\begin{array}{c}-0.027 \\
(0.109)\end{array}$ \\
\hline Percentage of Total Revenue from Federal and State Sources & $\begin{array}{r}-0.065^{*} \\
(0.035)\end{array}$ & $\begin{array}{l}0.003^{* * *} \\
(0.001)\end{array}$ \\
\hline Percentage of Property Tax Base from Businesses & $\begin{array}{c}-0.047 \\
(0.075)\end{array}$ & $\begin{array}{l}0.004^{* * *} \\
(0.001)\end{array}$ \\
\hline Percentage of Registered Republican Voters & $\begin{array}{l}0.198^{* * *} \\
(0.053)\end{array}$ & $\begin{array}{c}-0.006^{* * *} \\
(0.002)\end{array}$ \\
\hline Percentage of Population Aged 65 and Older & $\begin{array}{c}-0.028 \\
(0.098)\end{array}$ & $\begin{array}{c}-0.003 \\
(0.003)\end{array}$ \\
\hline Percentage of Adults with a Bachelor's Degree or Higher & $\begin{array}{c}0.068 \\
(0.046)\end{array}$ & $\begin{array}{l}0.004^{* * *} \\
(0.001)\end{array}$ \\
\hline Percentage of Owner-occupied Housing Units & $\begin{array}{l}0.057 \\
(0.055)\end{array}$ & $\begin{array}{c}0.003 \\
(0.002)\end{array}$ \\
\hline Dummy for Bordering Massachusetts & $\begin{array}{c}1.740 \\
(1.362)\end{array}$ & $\begin{array}{c}-0.017 \\
(0.022)\end{array}$ \\
\hline Dummy for Bordering New York & $\begin{array}{c}-2.214^{* * *} \\
(0.761)\end{array}$ & $\begin{array}{c}0.021 \\
(0.039)\end{array}$ \\
\hline Dummy for Bordering Rhode Island & $\begin{array}{c}-0.240 \\
(1.624)\end{array}$ & $\begin{array}{r}-0.078^{*} \\
(0.042)\end{array}$ \\
\hline Constant & $\begin{array}{l}109.796^{* * *} \\
(13.016)\end{array}$ & $\begin{array}{c}-0.123 \\
(0.730)\end{array}$ \\
\hline Observations & 585 & 585 \\
\hline Endogeneity Test P-value & & 0.052 \\
\hline Kleibergen-Paap Underidentification Test P-value & & 0.017 \\
\hline Hansen J Overidentification Test P-value & & 0.218 \\
\hline Adjusted R-squared & 0.908 & 0.574 \\
\hline
\end{tabular}

Source: Author's calculations

Notes: All regressions include year and labor market area (LMA) fixed effects. Standard errors are clustered at the school district level.

${ }^{*} p<0.10,{ }^{* *} p<0.05,{ }^{* * *} p<0.01$ 
Table 3. Regression Results From Robustness Checks (Part A) 2009-2013 (Unless Otherwise Noted)

\begin{tabular}{|c|c|c|c|c|c|}
\hline \multirow{2}{*}{$\begin{array}{l}\text { Dependent Variable: } \\
\text { Log of Current Spending per Pupil }\end{array}$} & \multirow{2}{*}{$\begin{array}{c}\text { Preferred } \\
\text { Specification }\end{array}$} & \multicolumn{2}{|c|}{ Alternative Measures of } & \multirow{2}{*}{$\begin{array}{c}\text { Excluding } \\
\text { Pseudo } \\
\text { Regional K-12 } \\
\text { Districts } \\
(4) \\
\end{array}$} & \multirow{2}{*}{$\begin{array}{l}\text { Excluding } \\
2009 \text { and } \\
2010 \\
\text { Data } \\
(5)\end{array}$} \\
\hline & & $\begin{array}{c}\text { Low- } \\
\text { income } \\
\text { Students } \\
(2)\end{array}$ & $\begin{array}{c}\text { Economies } \\
\text { of } \\
\text { Scale } \\
(3)\end{array}$ & & \\
\hline \multicolumn{6}{|l|}{ Cost Factors: } \\
\hline Percentage of School-age Children (Aged 5-17) from Families Living in Poverty & $\begin{array}{l}0.012^{* *} \\
(0.005)\end{array}$ & & $\begin{array}{c}0.011^{*} \\
(0.006)\end{array}$ & $\begin{array}{c}0.013^{* *} \\
(0.005)\end{array}$ & $\begin{array}{l}0.012^{* *} \\
(0.006)\end{array}$ \\
\hline Percentage of Students Eligible for Free or Reduced-price Lunch & & $\begin{array}{l}0.006^{* *} \\
(0.003)\end{array}$ & & & \\
\hline Percentage of Children Enrolled in Public Schools Living in Single-parent or Non-family Households & $\begin{array}{c}0.003^{*} \\
(0.002)\end{array}$ & $\begin{array}{c}0.003^{*} \\
(0.002)\end{array}$ & $\begin{array}{l}0.003^{* *} \\
(0.001)\end{array}$ & $\begin{array}{c}0.003^{*} \\
(0.002)\end{array}$ & $\begin{array}{l}0.003^{* *} \\
(0.002)\end{array}$ \\
\hline Dummy for Enrollment $<2,000$ & $\begin{array}{l}0.072^{* * *} \\
(0.022)\end{array}$ & $\begin{array}{l}0.080^{* * *} \\
(0.022)\end{array}$ & & $\begin{array}{l}0.072^{* * *} \\
(0.022)\end{array}$ & $\begin{array}{l}0.071^{* * *} \\
(0.021)\end{array}$ \\
\hline Log of Total Enrollment & & & $\begin{array}{c}-0.560^{* * *} \\
(0.176)\end{array}$ & & \\
\hline Square of Log of Total Enrollment & & & $\begin{array}{l}0.031^{* * *} \\
(0.011)\end{array}$ & & \\
\hline Dummy for Regional School District & $\begin{array}{l}0.077^{* * *} \\
(0.019)\end{array}$ & $\begin{array}{l}0.085^{* * *} \\
(0.020)\end{array}$ & $\begin{array}{l}0.072^{* * *} \\
(0.018)\end{array}$ & $\begin{array}{l}0.082^{* * *} \\
(0.028)\end{array}$ & $\begin{array}{l}0.065^{\text {*** }} \\
(0.019)\end{array}$ \\
\hline Observations & 585 & 585 & 585 & 560 & 351 \\
\hline Adjusted R-squared & 0.574 & 0.552 & 0.614 & 0.559 & 0.596 \\
\hline
\end{tabular}

Source: Author's calculations

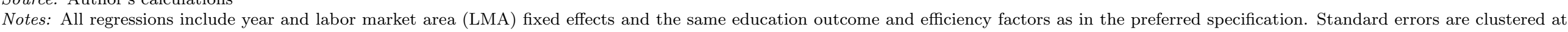

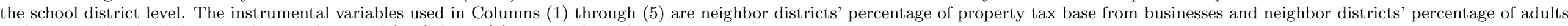
without a high school degree. The sample period for Column (5) is 2011 through 2013

*** $\mathrm{p}<0.01,{ }^{* *} \mathrm{p}<0.05,{ }^{*} \mathrm{p}<0.1$ 
Table 3. Regression Results From Robustness Checks (Part B)

2009-2013 (Unless Otherwise Noted)

\begin{tabular}{|c|c|c|c|c|c|c|c|c|c|c|c|c|c|c|c|}
\hline \multirow{2}{*}{$\begin{array}{l}\text { Dependent Variable: } \\
\text { Log of Current Spending per Pupil }\end{array}$} & \multirow{2}{*}{$\begin{array}{c}\text { Preferred } \\
\text { Specification }\end{array}$} & \multicolumn{14}{|c|}{ Alternative Measures of Education Outcomes } \\
\hline & & $\begin{array}{c}\text { Math } \\
\text { Proficiency } \\
\text { Only } \\
(6)\end{array}$ & $\begin{array}{c}\text { Reading } \\
\text { Proficiency } \\
\text { Only } \\
(7)\end{array}$ & $\begin{array}{c}\text { Writing } \\
\text { Proficiency } \\
\text { Only } \\
\text { (8) }\end{array}$ & $\begin{array}{c}\text { Average } \\
\text { Score } \\
\\
(9)\end{array}$ & $\begin{array}{l}\text { Math } \\
\text { Score } \\
\text { Only } \\
(10)\end{array}$ & $\begin{array}{l}\text { Reading } \\
\text { Score } \\
\text { Only } \\
(11)\end{array}$ & $\begin{array}{l}\text { Writing } \\
\text { Score } \\
\text { Only } \\
(12)\end{array}$ & $\begin{array}{l}\text { Elementary and } \\
\text { Middle School } \\
\text { Students' } \\
\text { Performance Only } \\
\text { (13) }\end{array}$ & $\begin{array}{c}\text { High } \\
\text { School } \\
\text { Students' } \\
\text { Performance Only } \\
(14)\end{array}$ & $\begin{array}{c}\text { High } \\
\text { School } \\
\text { Graduation } \\
\text { Rate } \\
\text { (15) }\end{array}$ & $\begin{array}{c}\text { Higher } \\
\text { Education } \\
\text { Entry } \\
\text { Rate } \\
(16)\end{array}$ & $\begin{array}{c}\text { Average } \\
\text { Growth } \\
\text { Only } \\
(17)\end{array}$ & $\begin{array}{c}\text { Average } \\
\text { Growth } \\
\text { and } \\
\text { Proficiency } \\
\text { (18) }\end{array}$ & $\begin{array}{c}\text { Average } \\
\text { Growth and } \\
\text { Average } \\
\text { Score } \\
\text { (19) }\end{array}$ \\
\hline \multicolumn{16}{|l|}{ Education Outcomes: } \\
\hline $\begin{array}{l}\text { Percentage of Students Reaching or Exceedin } \\
\text { Proficiency in Math, Reading, and Writing }\end{array}$ & $\begin{array}{l}0.010^{*} \\
(0.005)\end{array}$ & & & & & & & & & & & & & $\begin{array}{l}0.011^{* *} \\
(0.005)\end{array}$ & \\
\hline $\begin{array}{l}\text { Percentage of Students Reaching or Exceeding } \\
\text { Proficiency in Math }\end{array}$ & & $\begin{array}{l}0.009^{*} \\
(0.005)\end{array}$ & & & & & & & & & & & & & \\
\hline $\begin{array}{l}\text { Percentage of Students Reaching or Exceeding } \\
\text { Proficiency in Reading }\end{array}$ & & & $\begin{array}{l}0.010^{* *} \\
(0.005)\end{array}$ & & & & & & & & & & & & \\
\hline $\begin{array}{l}\text { Percentage of Students Reaching or Exceeding } \\
\text { Proficiency in Writing }\end{array}$ & & & & $\begin{array}{l}0.008 \\
(0.006)\end{array}$ & & & & & & & & & & & \\
\hline $\begin{array}{l}\text { Average Scale Score in Math, Reading, and } \\
\text { Writing }\end{array}$ & & & & & $\begin{array}{l}0.008^{* *} \\
(0.004)\end{array}$ & & & & & & & & & & $\begin{array}{l}0.009^{* *} \\
(0.004)\end{array}$ \\
\hline Average Scale Score in Math & & & & & & $\begin{array}{l}0.007^{* *} \\
(0.004)\end{array}$ & & & & & & & & & \\
\hline Average Scale Score in Reading & & & & & & & $\begin{array}{l}0.009^{* *} \\
(0.004)\end{array}$ & & & & & & & & \\
\hline Average Scale Score in Writing & & & & & & & & $\begin{array}{c}0.008^{*} \\
(0.005)\end{array}$ & & & & & & & \\
\hline $\begin{array}{l}\text { Percentage of Elementary and Middle School } \\
\text { Students Reaching or Exceeding Proficiency } \\
\text { in Math, Reading, and Writing }\end{array}$ & & & & & & & & & $\begin{array}{c}0.010^{*} \\
(0.006)\end{array}$ & & & & & & \\
\hline $\begin{array}{l}\text { Percentage of High School Students Reaching } \\
\text { or Exceeding Proficiency in Math, Reading, } \\
\text { and Writing }\end{array}$ & & & & & & & & & & $\begin{array}{l}0.00 *^{*} \\
(0.004)\end{array}$ & & & & & \\
\hline Four-year High School Graduation Rate & & & & & & & & & & & $\begin{array}{l}0.013 \\
(0.013)\end{array}$ & & & & \\
\hline $\begin{array}{l}\text { Percentage of High School Graduates } \\
\text { Pursuing Higher Education }\end{array}$ & & & & & & & & & & & & $\begin{array}{l}0.006^{* * *} \\
(0.002)\end{array}$ & & & \\
\hline Average Growth in Math and Reading & & & & & & & & & & & & & $\begin{array}{c}-0.015 \\
(0.013)\end{array}$ & $\begin{array}{c}-0.009 \\
(0.012)\end{array}$ & $\begin{array}{c}-0.004 \\
(0.013)\end{array}$ \\
\hline \multicolumn{16}{|l|}{ Cost Factors: } \\
\hline $\begin{array}{l}\text { Percentage of School-age Children (Aged 5-17) } \\
\text { from Families Living in Poverty }\end{array}$ & $\begin{array}{l}0.012^{* *} \\
(0.005)\end{array}$ & $\begin{array}{l}0.013^{* *} \\
(0.005)\end{array}$ & $\begin{array}{l}0.013^{* *} \\
(0.005)\end{array}$ & $\begin{array}{l}0.010^{* *} \\
(0.005)\end{array}$ & $\begin{array}{l}0.012^{* *} \\
(0.005)\end{array}$ & $\begin{array}{l}0.012^{* *} \\
(0.005)\end{array}$ & $\begin{array}{l}0.012^{* *} \\
(0.005)\end{array}$ & $\begin{array}{l}0.012^{* *} \\
(0.005)\end{array}$ & $\begin{array}{l}0.012^{* *} \\
(0.005)\end{array}$ & $\begin{array}{l}0.010^{* *} \\
(0.004)\end{array}$ & $\begin{array}{c}0.011 \\
(0.007)\end{array}$ & $\begin{array}{c}0.004^{*} \\
(0.003)\end{array}$ & $\begin{array}{l}0.005^{* *} \\
(0.002)\end{array}$ & $\begin{array}{l}0.014^{* * *} \\
(0.005)\end{array}$ & $\begin{array}{l}0.013^{* * *} \\
(0.005)\end{array}$ \\
\hline $\begin{array}{l}\text { Percentage of Children Enrolled in Public } \\
\text { Schools Living in Single-parent or } \\
\text { Non-family Households }\end{array}$ & $\begin{array}{l}0.000^{*} \\
(0.002)\end{array}$ & $\begin{array}{l}0.000^{*} \\
(0.002)\end{array}$ & $\begin{array}{l}0.004^{* *} \\
(0.002)\end{array}$ & $\begin{array}{l}0.000^{*} \\
(0.002)\end{array}$ & $\begin{array}{l}0.004^{* *} \\
(0.002)\end{array}$ & $\begin{array}{l}0.004^{* *} \\
(0.002)\end{array}$ & $\begin{array}{l}0.004^{* *} \\
(0.002)\end{array}$ & $\begin{array}{l}0.000^{*} \\
(0.002)\end{array}$ & $\begin{array}{l}0.000^{*} \\
(0.002)\end{array}$ & $\begin{array}{c}0.003^{*} \\
(0.002)\end{array}$ & $\begin{array}{l}0.002 \\
(0.002)\end{array}$ & $\begin{array}{c}0.003^{*} \\
(0.001)\end{array}$ & $\begin{array}{l}0.001 \\
(0.002)\end{array}$ & $\begin{array}{l}0.003 \\
(0.002)\end{array}$ & $\begin{array}{c}0.000^{*} \\
(0.002)\end{array}$ \\
\hline Dummy for Enrollment $<2,000$ & $\begin{array}{l}0.072^{* * *} \\
(0.022)\end{array}$ & $\begin{array}{l}0.069^{* * *} \\
(0.020)\end{array}$ & $\begin{array}{l}0.075^{* * *} \\
(0.023)\end{array}$ & $\begin{array}{l}0.071^{* * *} \\
(0.022)\end{array}$ & $\begin{array}{l}0.068^{* * *} \\
(0.022)\end{array}$ & $\begin{array}{l}0.070^{* * *} \\
(0.020)\end{array}$ & $\begin{array}{l}0.070^{* * *} \\
(0.023)\end{array}$ & $\begin{array}{l}0.066^{* * *} \\
(0.024)\end{array}$ & $\begin{array}{l}0.072^{* * *} \\
(0.022)\end{array}$ & $\begin{array}{l}0.069^{* * *} \\
(0.022)\end{array}$ & $\begin{array}{l}0.062^{* * *} \\
(0.021)\end{array}$ & $\begin{array}{l}0.071^{* * *} \\
(0.022)\end{array}$ & $\begin{array}{l}0.064^{* * *} \\
(0.022)\end{array}$ & $\begin{array}{l}0.073^{* * *} \\
(0.023)\end{array}$ & $\begin{array}{l}0.068^{* * *} \\
(0.022)\end{array}$ \\
\hline Dummy for Regional School District & $\begin{array}{l}0.077 * * * \\
(0.019)\end{array}$ & $\begin{array}{l}0.075^{* * *} \\
(0.018)\end{array}$ & $\begin{array}{l}0.074^{* * *} \\
(0.019)\end{array}$ & $\begin{array}{l}0.080^{* * *} \\
(0.020)\end{array}$ & $\begin{array}{l}0.076^{* * *} \\
(0.020)\end{array}$ & $\begin{array}{l}0.083^{* * *} \\
(0.020)\end{array}$ & $\begin{array}{l}0.073^{* * *} \\
(0.021)\end{array}$ & $\begin{array}{l}0.071 * * * \\
(0.021)\end{array}$ & $\begin{array}{l}0.077^{* * *} \\
(0.019)\end{array}$ & $\begin{array}{l}0.078^{* * *} \\
(0.018)\end{array}$ & $\begin{array}{l}0.102^{* * *} \\
(0.035)\end{array}$ & $\begin{array}{l}0.096^{* * *} \\
(0.019)\end{array}$ & $\begin{array}{l}0.087^{* * *} \\
(0.023)\end{array}$ & $\begin{array}{l}0.091 * * * \\
(0.023)\end{array}$ & $\begin{array}{l}0.096^{* * *} \\
(0.023)\end{array}$ \\
\hline $\begin{array}{l}\text { Observations } \\
\text { Adjusted R-squared }\end{array}$ & $\begin{array}{l}585 \\
0.574\end{array}$ & $\begin{array}{r}585 \\
0.580\end{array}$ & $\begin{array}{c}585 \\
0.541\end{array}$ & $\begin{array}{r}585 \\
0.593\end{array}$ & $\begin{array}{r}585 \\
0.524\end{array}$ & $\begin{array}{r}585 \\
0.528\end{array}$ & $\begin{array}{l}585 \\
0.501\end{array}$ & $\begin{array}{l}585 \\
0.485\end{array}$ & $\begin{array}{l}585 \\
0.570\end{array}$ & $\begin{array}{c}585 \\
0.576\end{array}$ & $\begin{array}{l}590 \\
0.462\end{array}$ & $\begin{array}{l}456 \\
0.632\end{array}$ & $\begin{array}{r}565 \\
0.619\end{array}$ & $\begin{array}{c}565 \\
0.551\end{array}$ & $\begin{array}{r}565 \\
0.520\end{array}$ \\
\hline
\end{tabular}

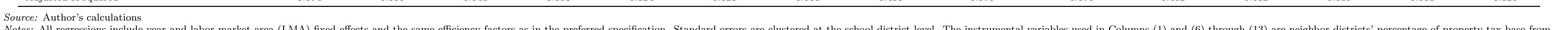

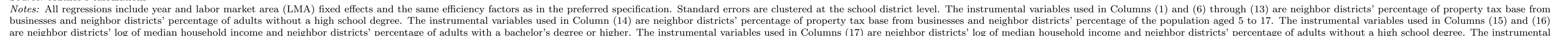

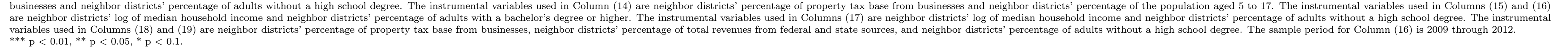


Table 4. Cost Index by District Characteristics

Five-year Average (2009-2013)

\begin{tabular}{|c|c|c|c|c|c|c|}
\hline & \multirow{2}{*}{$\begin{array}{l}\text { Cost } \\
\text { Index }\end{array}$} & \multicolumn{4}{|c|}{ Cost Factors } & \multirow{2}{*}{$\begin{array}{c}\text { Share of } \\
\text { Statewide } \\
\text { Enrollment }\end{array}$} \\
\hline & & $\begin{array}{c}\text { Percentage of } \\
\text { School-age Children } \\
\text { from Families Living } \\
\text { in Poverty }\end{array}$ & $\begin{array}{l}\text { Percentage of Children } \\
\text { Enrolled in Public Schools } \\
\text { Living in Single-parent } \\
\text { or Non-family Households }\end{array}$ & $\begin{array}{l}\text { Dummy for } \\
\text { Enrollment } \\
\quad<2,000\end{array}$ & $\begin{array}{l}\text { Dummy for } \\
\text { Regional } \\
\text { District }\end{array}$ & \\
\hline \multicolumn{7}{|c|}{ Enrollment Quintiles } \\
\hline 1 & 1.00 & 7.23 & 27.82 & 1.00 & 0.13 & 6.12 \\
\hline 2 & 0.93 & 6.58 & 25.20 & 0.09 & 0.24 & 10.83 \\
\hline 3 & 0.94 & 8.23 & 26.62 & 0.00 & 0.13 & 14.70 \\
\hline 4 & 0.90 & 5.95 & 21.56 & 0.00 & 0.12 & 21.75 \\
\hline 5 & 1.12 & 18.29 & 43.29 & 0.00 & 0.00 & 46.59 \\
\hline \multicolumn{7}{|c|}{ Poverty Quintiles } \\
\hline 1 & 0.86 & 3.49 & 15.29 & 0.05 & 0.21 & 17.24 \\
\hline 2 & 0.88 & 4.67 & 19.34 & 0.11 & 0.13 & 15.29 \\
\hline 3 & 0.92 & 5.99 & 23.28 & 0.17 & 0.17 & 12.71 \\
\hline 4 & 0.96 & 9.06 & 31.46 & 0.10 & 0.00 & 17.32 \\
\hline 5 & 1.20 & 22.79 & 51.29 & 0.01 & 0.00 & 37.44 \\
\hline \multicolumn{7}{|c|}{ Property Wealth Quintiles } \\
\hline 1 & 1.23 & 23.88 & 53.40 & 0.05 & 0.02 & 29.86 \\
\hline 2 & 0.95 & 8.11 & 28.05 & 0.14 & 0.17 & 13.31 \\
\hline 3 & 0.90 & 6.30 & 23.72 & 0.06 & 0.05 & 20.18 \\
\hline 4 & 0.93 & 7.70 & 25.26 & 0.07 & 0.13 & 17.28 \\
\hline 5 & 0.91 & 7.07 & 22.58 & 0.07 & 0.09 & 19.36 \\
\hline \multicolumn{7}{|c|}{ Cost Index Quintiles } \\
\hline 1 & 0.85 & 3.90 & 15.26 & 0.00 & 0.00 & 19.96 \\
\hline 2 & 0.89 & 5.33 & 21.20 & 0.06 & 0.10 & 16.42 \\
\hline 3 & 0.93 & 6.65 & 25.61 & 0.11 & 0.27 & 15.47 \\
\hline 4 & 0.99 & 11.08 & 33.19 & 0.13 & 0.07 & 18.39 \\
\hline 5 & 1.25 & 25.07 & 55.82 & 0.07 & 0.02 & 29.76 \\
\hline
\end{tabular}

Source: Author's calculations

Notes: The five-year average enrollment of each district is used as the weight to calculate the weighted average values for each quintile. Property wealth per pupil is measured as Equalized Net Grand List (ENGL) per pupil. Quintiles are ranked from low to high. 
Table 5. Comparing Disparities in Cost-adjusted Spending with Disparities in Unadjusted Current Spending

Five-year Average (2009-2013)

\begin{tabular}{lcc}
\hline & $\begin{array}{c}\text { Current Spending } \\
\text { per Pupil }\end{array}$ & $\begin{array}{c}\text { Cost-adjusted Current Spending } \\
\text { per Pupil }\end{array}$ \\
\hline Range & 10.62 & 13.30 \\
$\frac{\text { Maximum }}{\text { Minimum }}$ & 1.90 & 2.33 \\
$\frac{90^{t h} \text { Percentile }}{10^{t h} \text { Percentile }}$ & 1.32 & 1.66 \\
$\frac{80^{t h} \text { Percentile }}{20^{t h} \text { Percentile }}$ & 1.24 & 1.38 \\
Gini Coefficient & 0.07 & 0.10 \\
Coefficient of Variation & 0.12 & 0.19 \\
\hline
\end{tabular}

Source: Author's calculations

Notes: The five-year average enrollment of each district is used as the weight to calculate the disparity measures. Both cost-adjusted current spending per pupil and unadjusted current spending per pupil are in thousands of 2013 dollars. 
Table 6. Cost-adjusted Current Spending per Pupil by District Characteristics

Five-year Average (2009-2013)

\begin{tabular}{cccc}
\hline & $\begin{array}{c}\text { Cost-adjusted Current Spending per Pupil } \\
\text { (Thousands of 2013 Dollars) }\end{array}$ & $\begin{array}{c}\text { Unadjusted Current Spending per Pupil } \\
\text { (Thousands of 2013 Dollars) }\end{array}$ & $\begin{array}{c}\text { Cost } \\
\text { Index }\end{array}$ \\
\hline Enrollment Quintiles & & & 1.00 \\
1 & 15.16 & 15.07 & 0.93 \\
2 & 15.62 & 14.42 & 0.94 \\
3 & 15.33 & 14.30 & 0.90 \\
4 & 16.71 & 14.87 & 1.12 \\
5 & 14.07 & 15.20 & 0.86 \\
1 & & & 0.88 \\
2 & 17.37 & 14.94 & 0.92 \\
3 & 16.14 & 14.24 & 0.96 \\
4 & 16.61 & 15.18 & 1.20 \\
\hline Poverty Quintiles & 15.48 & 14.76 & 1.23 \\
1 & 12.84 & 15.13 & 0.95 \\
2 & & & 0.90 \\
3 & 12.10 & 14.69 & 0.93 \\
5 & 14.58 & 13.81 & 0.91 \\
\hline Property Wealth Quintiles & 15.63 & 14.11 & \\
1 & 15.71 & 14.58 & 0.85 \\
2 & 18.80 & 17.09 & 0.89 \\
4 & & & 0.93 \\
5 & 17.59 & 14.90 & 0.99 \\
\hline Cost Index Quintiles & 16.22 & 14.43 & 1.25 \\
\hline
\end{tabular}

Source: Author's calculations

Notes: The five-year average enrollment of each district is used as the weight to calculate the weighted average values for each quintile.

Property wealth per pupil is measured as Equalized Net Grand List (ENGL) per pupil. Quintiles are ranked from low to high. 
Table 7. Spending-to-cost Ratio by District Characteristics

Five-year Average (2009-2013)

\begin{tabular}{|c|c|c|c|}
\hline & Spending-to-cost Ratio & $\begin{array}{l}\text { Current Spending per Pupil } \\
\text { (Thousands of } 2013 \text { Dollars) }\end{array}$ & $\begin{array}{l}\text { Predicted Cost per Pupil } \\
\text { (Thousands of } 2013 \text { Dollars) }\end{array}$ \\
\hline \multicolumn{4}{|c|}{ Enrollment Quintiles } \\
\hline 1 & 0.92 & 15.07 & 16.46 \\
\hline 2 & 0.95 & 14.42 & 15.30 \\
\hline 3 & 0.93 & 14.30 & 15.50 \\
\hline 4 & 1.01 & 14.87 & 14.78 \\
\hline 5 & 0.85 & 15.20 & 18.40 \\
\hline \multicolumn{4}{|c|}{ Poverty Quintiles } \\
\hline 1 & 1.05 & 14.94 & 14.22 \\
\hline 2 & 0.98 & 14.24 & 14.57 \\
\hline 3 & 1.01 & 15.18 & 15.09 \\
\hline 4 & 0.94 & 14.76 & 15.75 \\
\hline 5 & 0.78 & 15.13 & 19.78 \\
\hline \multicolumn{4}{|c|}{ Property Wealth Quintiles } \\
\hline 1 & 0.73 & 14.69 & 20.30 \\
\hline 2 & 0.88 & 13.81 & 15.70 \\
\hline 3 & 0.95 & 14.11 & 14.91 \\
\hline 4 & 0.95 & 14.58 & 15.35 \\
\hline 5 & 1.14 & 17.09 & 15.08 \\
\hline \multicolumn{4}{|c|}{ Cost Index Quintiles } \\
\hline 1 & 1.07 & 14.90 & 13.99 \\
\hline 2 & 0.98 & 14.43 & 14.67 \\
\hline 3 & 0.96 & 14.71 & 15.36 \\
\hline 4 & 0.93 & 15.12 & 16.34 \\
\hline 5 & 0.74 & 15.13 & 20.66 \\
\hline
\end{tabular}

Source: Author's calculations

Notes: The predicted cost per pupil is calculated under the assumption that the student test performance target is 90 percent of students reaching or exceeding the proficiency level. The five-year average enrollment of each district is used as the weight to calculate the weighted average values for each quintile. Property wealth per pupil is measured as Equalized Net Grand List (ENGL) per pupil. Quintiles are ranked from low to high. 
Table 8. Additional Spending Needed by District Characteristics

Five-year Average (2009-2013)

\begin{tabular}{cccc}
\hline & $\begin{array}{c}\text { Additional Spending Needed as } \\
\text { Percentage of Current Spending } \\
(\%)\end{array}$ & $\begin{array}{c}\text { Additional Spending Needed } \\
\text { per Pupil } \\
\text { (Thousands of 2013 Dollars) }\end{array}$ & $\begin{array}{c}\text { Current Spending per Pupil } \\
\text { (Thousands of 2013 Dollars) }\end{array}$ \\
\hline Enrollment Quintiles & 12.83 & & 15.07 \\
1 & 10.07 & 1.75 & 14.42 \\
2 & 10.76 & 1.48 & 14.30 \\
3 & 5.93 & 0.81 & 14.87 \\
4 & 24.64 & 3.60 & 15.20 \\
5 & & & 14.94 \\
Poverty Quintiles & 3.54 & 0.45 & 14.24 \\
1 & 6.52 & 0.85 & 14.18 \\
2 & 6.40 & 0.84 & 14.76 \\
4 & 8.80 & 1.22 & 13 \\
5 & 32.81 & 4.80 & 13.69 \\
1 & & & 14.81 \\
2 & 38.09 & 5.60 & 14.58 \\
4 & 15.08 & 1.99 & 17.09 \\
\hline Property Wealth Quintiles & 6.40 & 0.88 & \\
1 & 8.02 & 1.06 & 14.90 \\
2 & 0.94 & 0.13 & 14.43 \\
4 & & & 14.71 \\
5 & 2.79 & 0.35 & 15.12 \\
\hline Cost Index Quintiles & 7.02 & 0.91 & 15.13 \\
\hline
\end{tabular}

Source: Author's calculations

Notes: The additional spending needed per pupil is calculated under the assumption that the student test performance target is 90 percent of students reaching or exceeding the proficiency level. The five-year average enrollment of each district is used as the weight to calculate the weighted average values for each quintile. Property wealth per pupil is measured as Equalized Net Grand List (ENGL) per pupil. Quintiles are ranked from low to high. 
Figure 1. Cost Index by Connecticut School District Five-year Average (2009-2013)

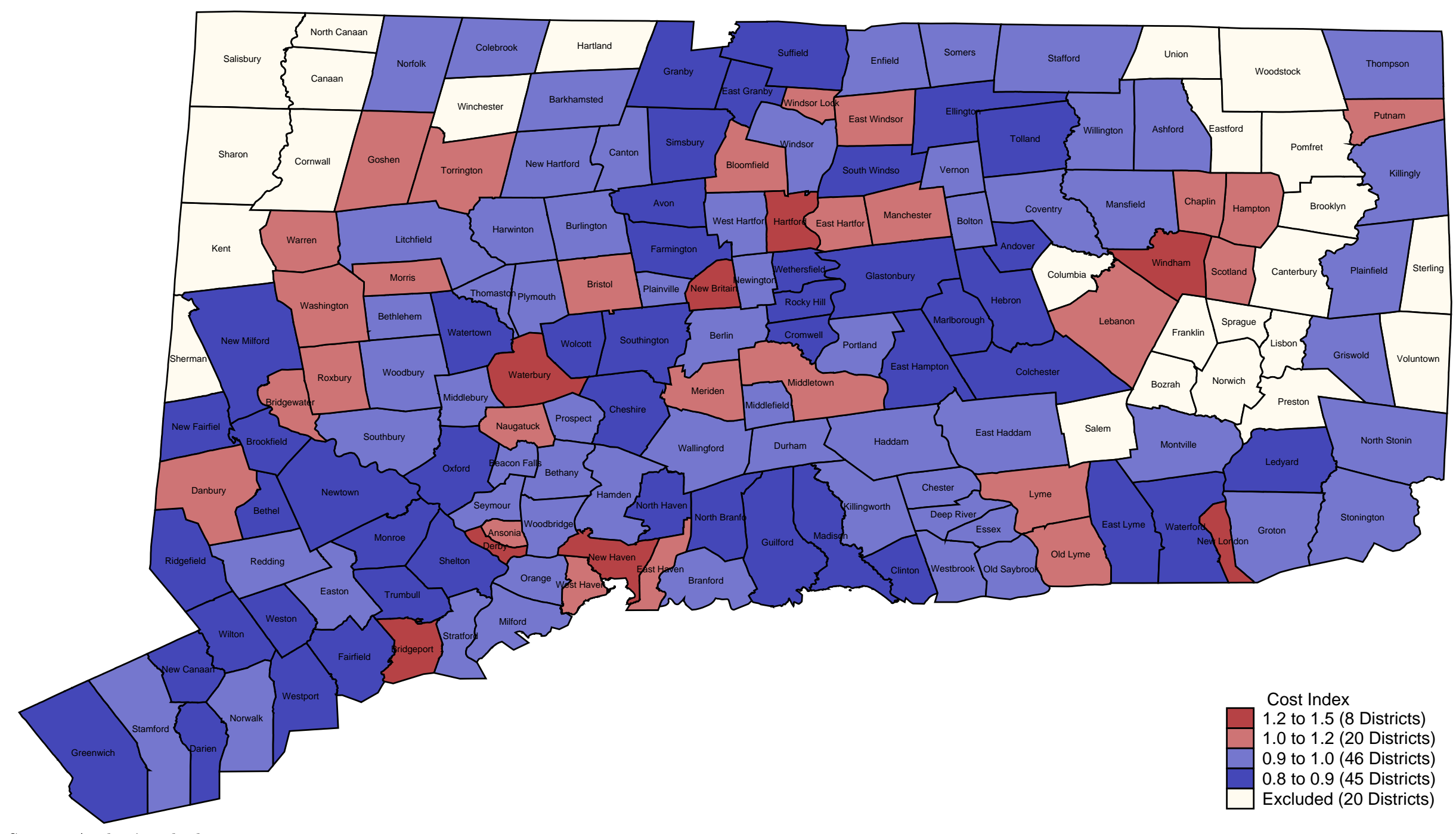

Source: Author's calculations

Note: School districts are excluded due to missing data 
Figure 2. Spending-to-cost Ratio by Connecticut School District Five-year Average (2009-2013)

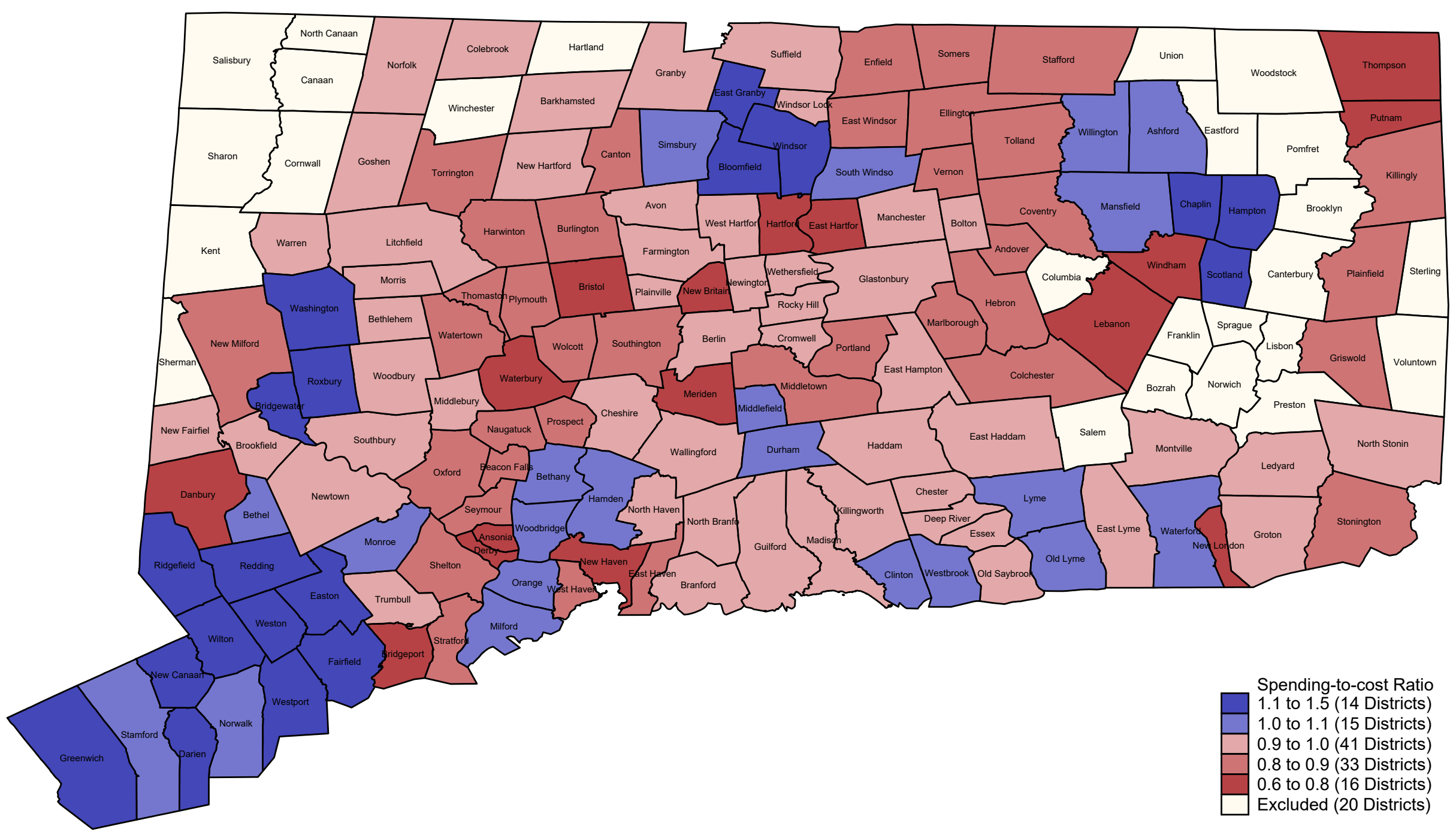

Source: Author's calculations

Notes: School districts are excluded due to missing data. The predicted cost per pupil is calculated under the assumption that the student test performance target is 90 percent of students reaching or exceeding the proficiency level. 
Figure 3. Percentage of Students Reaching or Exceeding Proficiency versus Current Spending per Pupil

117 K-12 School Districts in Connecticut, 2009-2013

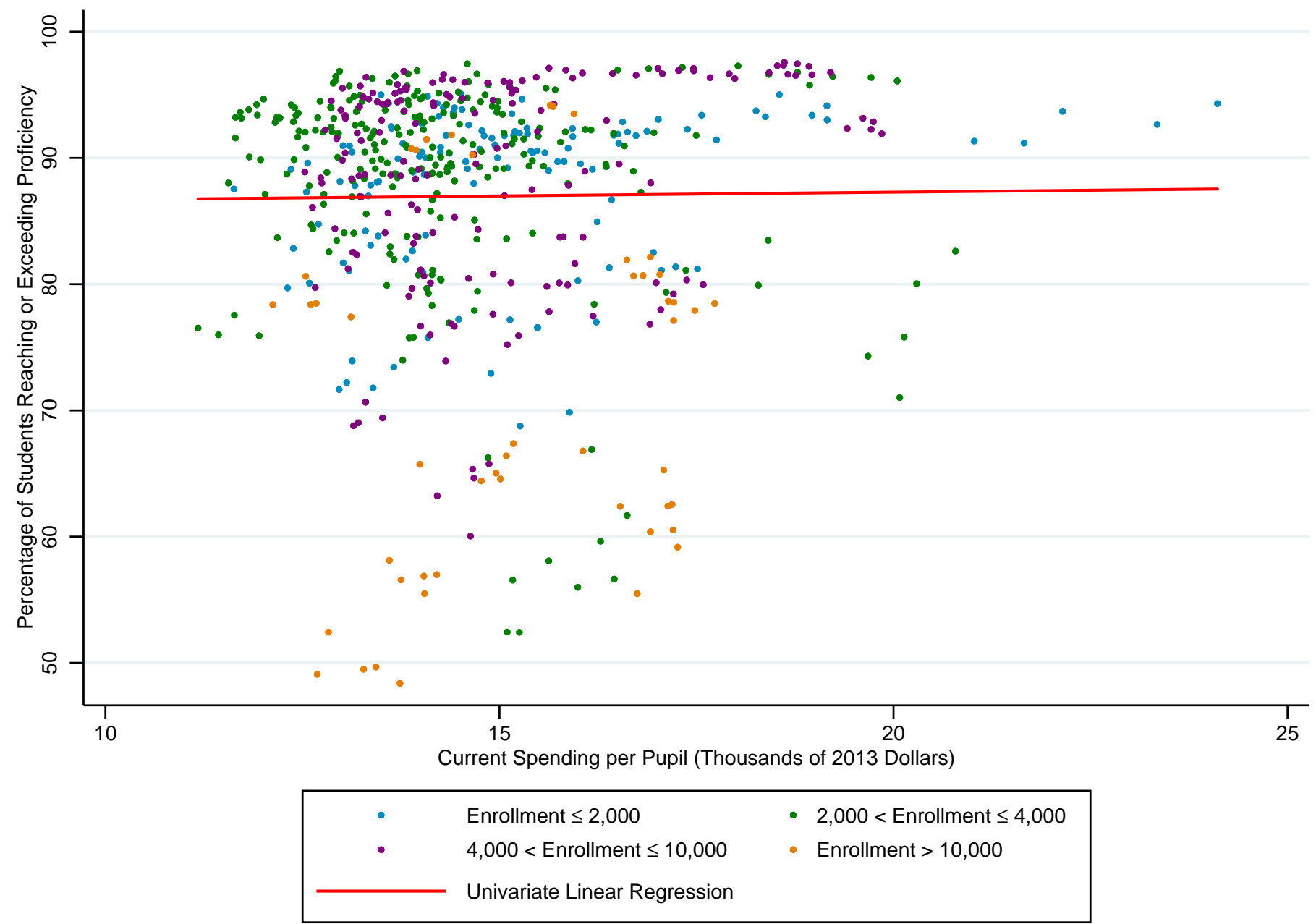

Source: Author's calculations

Note: The red straight line is generated from a univariate regression that describes a simple linear relationship between the two variables in question. 
Figure 4. Student Performance Gap versus Spending Gap per Pupil

117 K-12 School Districts in Connecticut, 2009-2013

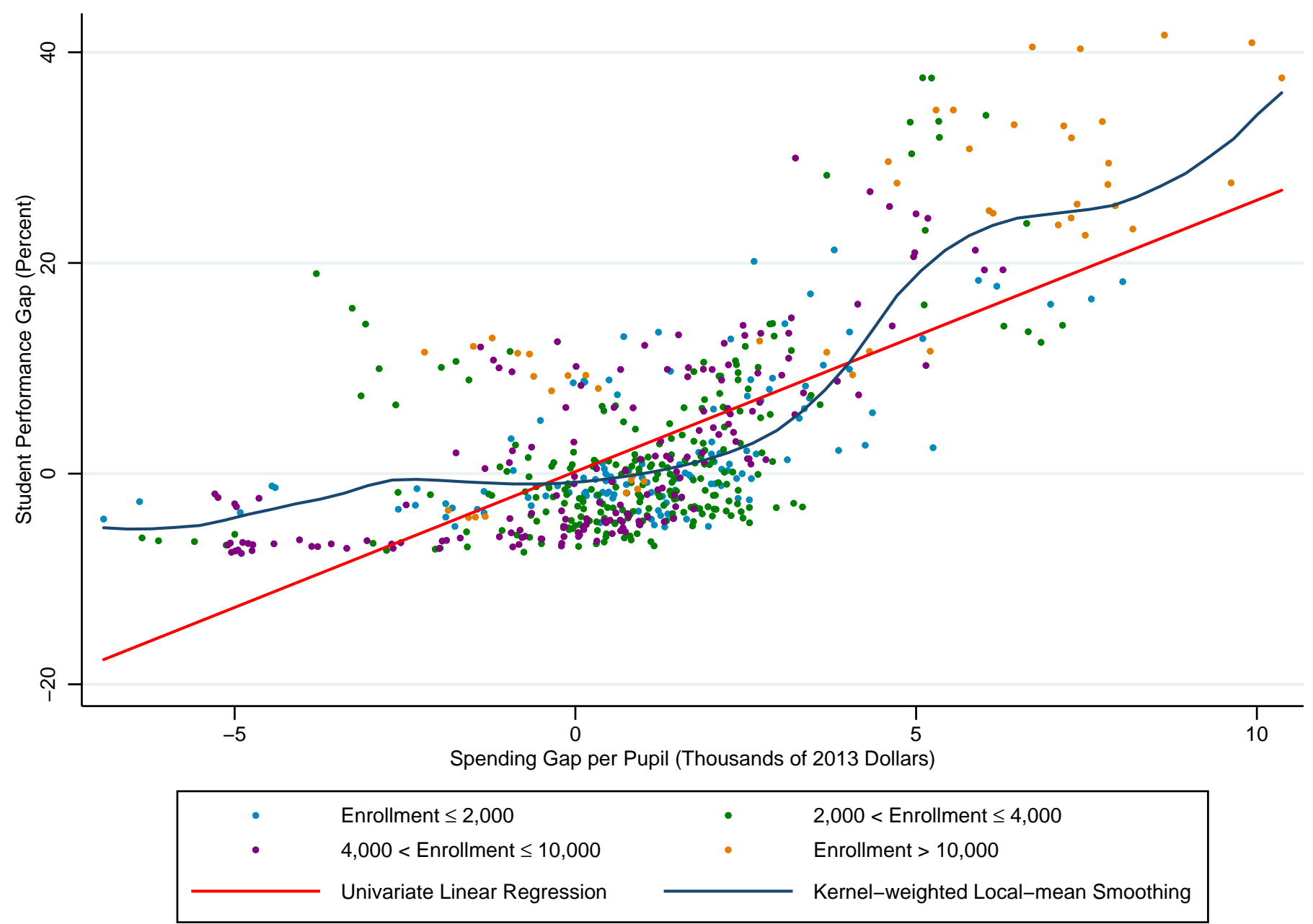

Source: Author's calculations

Notes: Student performance gap is calculated by subtracting the percentage of students reaching or exceeding the proficiency level from 90. Spending gap per pupil is calculated by subtracting current spending per pupil from the predicted cost per pupil of achieving the target of having 90 percent of students reach or exceed the proficiency l evel. The r ed straight line is g enerated from a univariate regression that describes a simple linear relationship between the two variables in question. The blue curved line is obtained from the kernel-weighted local-mean smoothing using the Epanechnikov kernel and the bandwidth of 1 . 
Appendix Table 1. Data Sources

Variable $\quad$ Source

Dependent Variable:

Log of Current Spending per Pupil

Education Outcomes:

Percentage of Students Reaching or Exceeding Proficiency in Math, Reading, and Writing

Average Scale Score in Math, Reading, and Writing

Average Growth in Math and Reading

High School Graduation Rates

Percentage of High School Graduates Pursuing Higher

Education

Cost Factors:

Percentage of School-age Children (Aged 5-17) from Families Living in Poverty

Percentage of Children Enrolled in Public Schools Living in Single-parent or Non-family Households

Dummy for Enrollment $<2,000$

Dummy for Regional School District

Percentage of Students Eligible for Free or Reducedprice Lunch

Log of Student Enrollment

Efficiency Variables:

Log of Real Equalized Net Grand List (ENGL) per Pupil

Log of Median Household Income

Percentage of Total Revenue from Federal and State Sources

Percentage of Property Tax Base from Businesses

Percentage of Registered Republican Voters

Percentage of Population Aged 65 and Older

Percentage of Adults with a Bachelor's Degree or Higher

Percentage of Owner-occupied Housing Units

Other Variables:

Percentage of Students Who Are Black

Percentage of Students Who Are Hispanic

Percentage of English-learner Students

Percentage of Students with Special Needs

Percentage of Students in Grades 9-12

Population Density

Percentage of Population Receiving Temporary Assistance for Needy Families (TANF)

Percentage of Students Who Were Identified as Homeless

Number of Children under Age 19 Enrolled in HUSKY A per Pupil

Percentage of Children Enrolled in Public Schools Who Are Foreign-born

Percentage of Population Aged 5-17

Percentage of Parents of Children Enrolled in Public Schools without a High School Degree

Percentage of Adults without a High School Degree

Consumer Price Index for All Urban Consumers (CPIU), Northeast Region

Education Comparable Wage Index (ECWI)
National Center for Education Statistics, Common Core of Data, Local Education Agency Finance Survey (F-33)

Connecticut Department of Education

Connecticut Department of Education

Connecticut Department of Education

Connecticut Department of Education

Connecticut Department of Education

US Census Bureau, Small Area Income and Poverty Estimates

American Community Survey: Special Tabulation for National Center for Education Statistics

National Center for Education Statistics, Common Core of Data, Universe Surveys Connecticut Department of Education

National Center for Education Statistics, Common Core of Data, Universe Surveys

National Center for Education Statistics, Common Core of Data, Universe Surveys

Connecticut Office of Policy and Management, Municipal Fiscal Indicator Report

American Community Survey: Special Tabulation for National Center for Education Statistics

National Center for Education Statistics, Common Core of Data, Local Education Agency Finance Survey (F-33)

Connecticut Office of Policy and Management, Municipal Fiscal Indicator Report Connecticut Office of the Secretary of State

American Community Survey: Special Tabulation for National Center for Education Statistics

American Community Survey: Special Tabulation for National Center for Education Statistics

American Community Survey: Special Tabulation for National Center for Education Statistics

National Center for Education Statistics, Common Core of Data, Universe Surveys National Center for Education Statistics, Common Core of Data, Universe Surveys National Center for Education Statistics, Common Core of Data, Universe Surveys National Center for Education Statistics, Common Core of Data, Universe Surveys National Center for Education Statistics, Common Core of Data, Universe Surveys Connecticut Office of Policy and Management, Municipal Fiscal Indicator Report

Connecticut Office of Policy and Management, Municipal Fiscal Indicator Report

Connecticut Department of Education

Connecticut Department of Social Services

American Community Survey: Special Tabulation for National Center for Education Statistics

American Community Survey: Special Tabulation for National Center for Education Statistics

American Community Survey: Special Tabulation for National Center for Education Statistics

American Community Survey: Special Tabulation for National Center for Education Statistics

US Bureau of Labor Statistics

Professor Lori Taylor, Texas A\&M University 


\section{Appendix Table 2. Composition of Current Spending per Pupil by District Characteristics}

Five-year Average (2009-2013)

\begin{tabular}{|c|c|c|c|c|c|c|c|}
\hline & $\begin{array}{l}\text { Current } \\
\text { Spending } \\
\text { per Pupil } \\
\\
\text { (Thousands of } \\
\text { 2013 Dollars) }\end{array}$ & $\begin{array}{l}\text { Current Spending } \\
\text { on Instruction } \\
\text { per Pupil } \\
\\
\text { (Thousands of } \\
2013 \text { Dollars) }\end{array}$ & $\begin{array}{c}\text { Current Spending } \\
\text { on Support } \\
\text { Services } \\
\text { per Pupil } \\
\text { (Thousands of } \\
\text { 2013 Dollars) }\end{array}$ & $\begin{array}{c}\text { Current Spending } \\
\text { on Other } \\
\text { Programs } \\
\text { per Pupil } \\
\text { (Thousands of } \\
2013 \text { Dollars) }\end{array}$ & $\begin{array}{l}\text { Share of Current } \\
\text { Spending on } \\
\text { Instruction } \\
(\%)\end{array}$ & $\begin{array}{c}\text { Share of Current } \\
\text { Spending on } \\
\text { Support } \\
\text { Services } \\
(\%)\end{array}$ & $\begin{array}{c}\text { Share of Current } \\
\text { Spending on } \\
\text { Other } \\
\text { Programs } \\
(\%)\end{array}$ \\
\hline \multicolumn{8}{|c|}{ Enrollment Quintiles } \\
\hline 1 & 15.07 & 9.76 & 5.09 & 0.22 & 64.76 & 33.78 & 1.46 \\
\hline 2 & 14.42 & 9.44 & 4.80 & 0.18 & 65.46 & 33.29 & 1.25 \\
\hline 3 & 14.30 & 9.51 & 4.62 & 0.18 & 66.50 & 32.31 & 1.26 \\
\hline 4 & 14.87 & 9.93 & 4.75 & 0.18 & 66.78 & 31.94 & 1.21 \\
\hline 5 & 15.20 & 10.21 & 4.84 & 0.15 & 67.17 & 31.84 & 0.99 \\
\hline \multicolumn{8}{|c|}{ Poverty Quintiles } \\
\hline 1 & 14.94 & 9.82 & 4.94 & 0.19 & 65.73 & 33.07 & 1.27 \\
\hline 2 & 14.24 & 9.49 & 4.57 & 0.19 & 66.64 & 32.09 & 1.33 \\
\hline 3 & 15.18 & 10.14 & 4.85 & 0.18 & 66.80 & 31.95 & 1.19 \\
\hline 4 & 14.76 & 9.82 & 4.77 & 0.17 & 66.53 & 32.32 & 1.15 \\
\hline 5 & 15.13 & 10.15 & 4.83 & 0.15 & 67.09 & 31.92 & 0.99 \\
\hline \multicolumn{8}{|c|}{ Property Wealth Quintiles } \\
\hline 1 & 14.69 & 9.86 & 4.69 & 0.15 & 67.12 & 31.93 & 1.02 \\
\hline 2 & 13.81 & 9.31 & 4.33 & 0.18 & 67.41 & 31.35 & 1.30 \\
\hline 3 & 14.11 & 9.22 & 4.70 & 0.19 & 65.34 & 33.31 & 1.35 \\
\hline 4 & 14.58 & 9.83 & 4.58 & 0.17 & 67.42 & 31.41 & 1.17 \\
\hline 5 & 17.09 & 11.32 & 5.60 & 0.17 & 66.24 & 32.77 & 0.99 \\
\hline \multicolumn{8}{|c|}{ Cost Index Quintiles } \\
\hline 1 & 14.90 & 9.77 & 4.94 & 0.20 & 65.57 & 33.15 & 1.34 \\
\hline 2 & 14.43 & 9.77 & 4.50 & 0.15 & 67.71 & 31.19 & 1.04 \\
\hline 3 & 14.71 & 9.70 & 4.83 & 0.19 & 65.94 & 32.83 & 1.29 \\
\hline 4 & 15.12 & 10.21 & 4.78 & 0.13 & 67.53 & 31.61 & 0.86 \\
\hline 5 & 15.13 & 10.09 & 4.87 & 0.17 & 66.69 & 32.19 & 1.12 \\
\hline
\end{tabular}

Source: Author's calculations

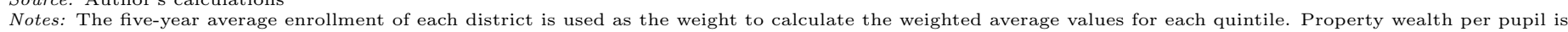
measured as Equalized Net Grand List (ENGL) per pupil. Quintiles are ranked from low to high. 
Appendix Table 3. Review of the Maximum-to-minimum Ratio for the Education Cost Index in Previous Studies

\begin{tabular}{lllc}
\hline \multirow{2}{*}{ Study } & State & \multirow{2}{*}{ Data Period } & Maximum of the Cost Index \\
\cline { 4 - 4 } & & & Minimum of the Cost Index \\
\hline Imazeki and Reschovsky (2006) & Texas & 2002 & 8.05 \\
Imazeki and Reschovsky (2004) & Texas & 2002 & 6.85 \\
Duncombe and Yinger (1999) & New York & 1991 & 5.12 \\
Imazeki (2001) & Illinois & 1998 & 3.96 \\
Duncombe and Yinger (2000) & New York & 1991 & 3.34 \\
Duncombe, Ruggiero, and Yinger (1996) & New York & 1991 & 3.09 \\
Gronberg et al. (2004) & Texas & $1999-2002$ & 2.79 \\
Duncombe (2002) & New York & 2000 & 2.27 \\
Duncombe and Yinger (2005a) & Kansas & $2000-2004$ & 2.01 \\
Duncombe and Yinger (2005b) & New York & 2001 & 1.81 \\
Reschovsky and Imazeki (2003) & Texas & 1996 & 1.57 \\
\hline
\end{tabular}

